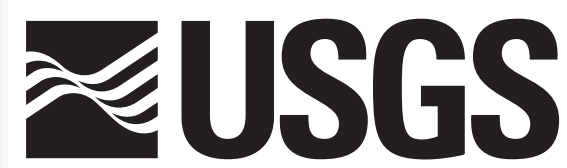

science for a changing world

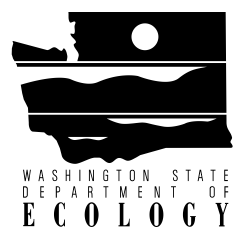

Non-navigational

GRIDDED BATHYMETRY DATA

Washington - Oregon Coast : 1926-1998

Data release and description of methods

Version 1.0

Ann E. Gibbs, Maarten C. Buijsman, and Chris R. Sherwood

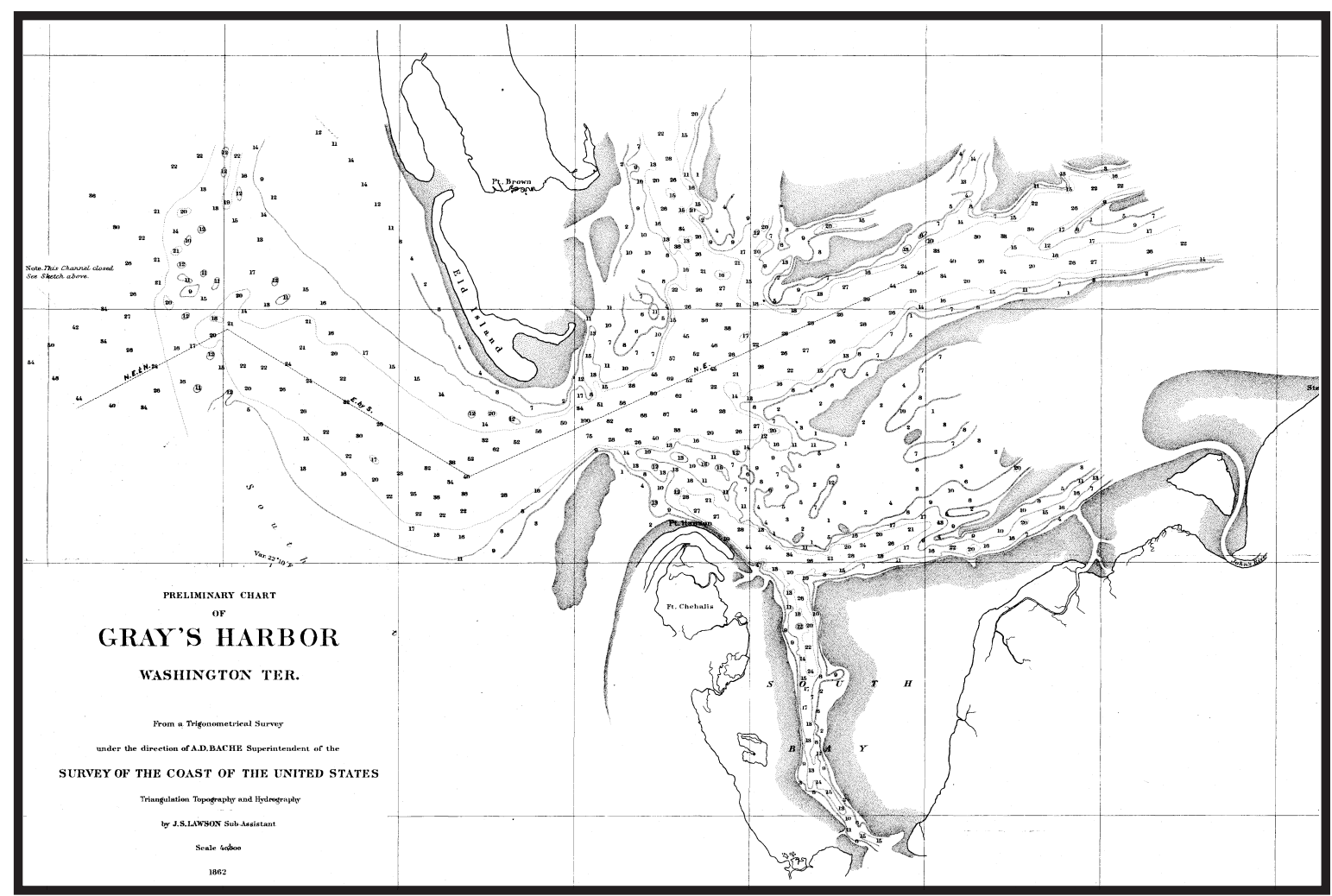

Open-File Report 00-448

Prepared in cooperation with

Washington State Department of Ecology

November 2000

U.S. Department of the Interior

U.S. Geological Survey 


\title{
Non-navigational Gridded Bathymetry Washington-Oregon Coast: 1926-1998 Data release and description of methods
}

\author{
Ann E. Gibbs ${ }^{1}$, Maarten C. Buijsman², and Chris R. Sherwood ${ }^{3}$
}

Open-File Report 00-448

Version 1.0

\begin{abstract}
${ }^{1}$ U.S. Geological Survey, Santa Cruz, California
${ }^{2}$ Washington Department of Ecology, Olympia, Washington

${ }^{3}$ U.S. Geological Survey, Menlo Park, California
\end{abstract}

This report is preliminary and has not been reviewed for conformity with U.S. Geological Survey editorial standards. Any use of trade names is for descriptive purposes only and does not imply endorsement by the U.S. Government. 
CONTENTS

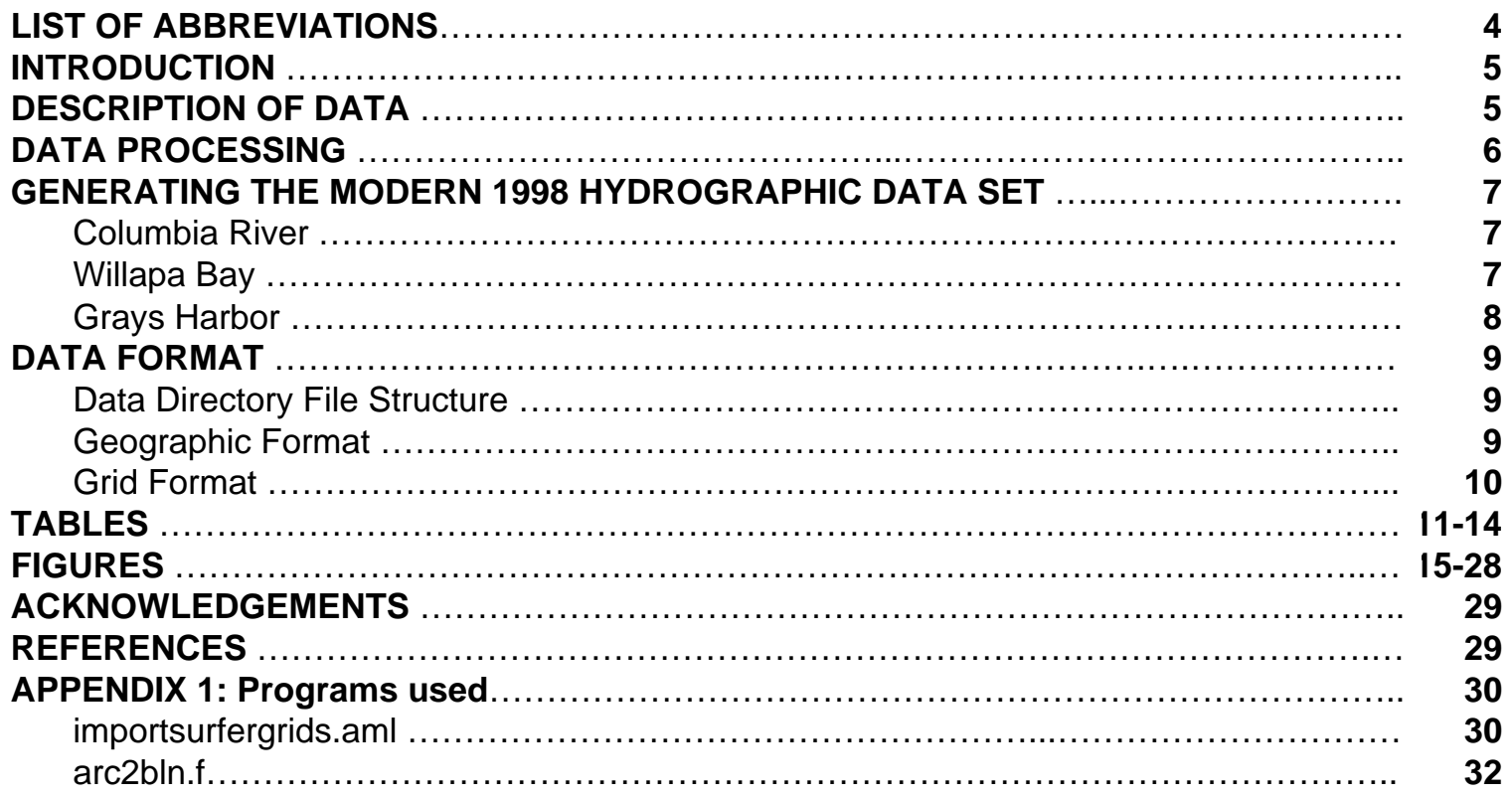

\section{LIST OF TABLES}

Table 1. NOS hydrographic surveys included in the Oregon-Washington (ORWA) data sets

Table 2. NOS and USACE hydrographic surveys included in the Southwest Washington (SWWA) data sets

Table 3. Boundaries of the SWWA grid

Table 4. Boundaries of the ORWA grid

Table 5. Processing steps used to create the SWWA26 grid

Table 6. Processing steps used to create the SWWA98 grid

Table 7. Processing steps used to create the ORWA26 and ORWA98 grids

\section{LIST OF FIGURES}

Fig. 1. NOS hydrographic surveys within the Oregon-Washington area (ORWA)

Fig. 2. NOS hydrographic surveys within the Southwest Washington area (SWWA)

Fig. 3. Boundaries of the 1998 USACE hydrographic surveys

Fig. 4. 1998 tracklines for the Columbia River approach and extension surveys

Fig. 5. Bathymetric contours from merged and edited 1926/1998 data, Columbia River

Fig. 6. Northern Columbia River inset maps

Fig. 7. Southern Columbia River inset maps

Fig. 8. Bathymetric contours from merged and edited 1926/1998 data, and location of 1998 survey tracklines, Willapa Bay

Fig. 9. Willapa Bay inset maps

Fig. 10. 1998 USACE annual survey tracklines for Grays Harbor

Fig. 11. Bathymetric contours from merged and edited 1926/1998 data, Grays Harbor

Fig. 12. Southern Grays Harbor inset maps

Fig. 13. Northern Grays Harbor inset maps 


$\begin{array}{ll}\text { ASCII } & \text { Standard text format } \\ \text { FAQ } & \text { Frequently Asked Question } \\ \text { FGDC } & \text { Federal Geographic Data Committee } \\ \text { HTML } & \text { Hypertext markup language } \\ \text { LIDAR } & \text { Llght Detection And Ranging } \\ \text { MAC } & \text { Apple Macintosh Computer/Operating System } \\ \text { MLLW } & \text { Mean Lower Low Water; vertical datum } \\ \text { NAD27 } & \text { North American Datum of 1927; horizontal datum } \\ \text { NAD83 } & \text { North American Datum of 1983; horizontal datum } \\ \text { NOAA } & \text { National Oceanic and Atmospheric Administration; U.S. Department of Commerce } \\ \text { NOS } & \text { National Ocean Service } \\ \text { ORWA } & \text { Oregon-Washington; boundary of large, regional data set } \\ \text { ORWA26 } & \text { Large, regional surface grid data set including historical data circa 1926 } \\ \text { ORWA98 } & \text { Large, regional surface grid data set including modern data circa 1998 } \\ \text { PC } & \text { Personal Computer (Microsoft Windows Operating System compatible) } \\ \text { SHOALS } & \text { Airborne LIDAR hydrographic data acquisition system } \\ \text { SWWA } & \text { Southwest Washington; boundary of study area data set } \\ \text { SWWA26 } & \text { Study area surface grid data set including historical data circa 1926 } \\ \text { SWWA98 } & \text { Study area surface grid data set including modern data circa 1998 } \\ \text { USACE } & \text { U.S. Army Corps of Engineers } \\ \text { USC\&GS } & \text { U.S. Coast and Geodetic Survey } \\ \text { USGS } & \text { U.S. Geological Survey } \\ \text { UTM } & \text { Universal Transverse Mercator } \\ \text { WASP } & \text { Washington Stateplane South }\end{array}$




\section{INTRODUCTION}

Sixteen digital bathymetric surface models (grids) of the seafloor off the coast of Washington and Oregon were created for wave modeling experiments along the coast of Washington. Surfaces were created for two areas over two time periods. The largest area (covering approximately 46 million $\mathrm{km}^{2}$ ) extends along the coast of Oregon and Washington, between Heceta Head OR and Cape Johnson WA, from the shoreline to about 2000 -m water depth (hereafter referred to as the ORWA region; Fig. 1). The second area (covering approximately 7 million $\mathrm{km}^{2}$ ) extends from Tillamook Head OR to Pt. Grenville WA, from the shore to approximately $700-\mathrm{m}$ water depth. This area corresponds to the study area boundaries of the Southwest Washington Coastal Erosion Study (Kaminsky et al., 1997, Gelfenbaum and Kaminsky, $1998 ; 1999$ ) and is hereafter referred to as the SWWA region (Fig. 2). Surfaces defined by the ORWA and SWWA regions were created for two time periods; historical (circa 1926), and modern (a combination of c.1926 and 1998 as discussed below). Data are presented in both UTM and Washington State Plane South coordinate systems, at 500-m and 750-m grid cell spacing, in ARC/INFO 7.1 (ESRI), SURFER 6.0 (Golden Software), and ASCll formats. The vertical datum is mean lower low water (MLLW).

This report describes the data sets used and the methodology and techniques applied to create the historical and modern bathymetric surfaces. A companion CD-ROM including the bathymetric surface data, shorelines, and bathymetric contours accompanies this report. These data are intended for scientific research and should not be used for navigational purposes. The use of trade names or products does not imply endorsement by the U.S. Geological Survey.

This work was conducted in conjunction with the Southwest Washington Coastal Erosion Study (SWCES), a cooperative project directed by the U.S. Geological Survey, Coastal and Marine Geology Program and the Washington State Department of Ecology. A description of the study and initial results can be found in Kaminsky et al. (1997) and Gelfenbaum and Kaminsky (1998 and 1999), and online at: http://www.ecy.wa/programs/sea/swce.

\section{DESCRIPTION OF DATA}

Original hydrographic sounding data were acquired from two sources: NOAA-National Ocean Service (NOS; formerly U.S. Coast and Geodetic Survey; USC\&GS; NGDC, 1998) and the U.S. Army Corps of Engineers (USACE, H. Rod Moritz and Eric Nelson, written comm.).

The historical sounding data (also referred to as the 1926 data) are originally from hydrographic surveys conducted between 1926 and 1974 by the NOS (Tables 1 and 2). The majority of historical data were collected between 1926 and 1930, however, where 1926-30 data did not exist, or were not available in digital format, data collected as recently as 1974 were used. These represent the most recent hydrographic surveys available on a region-wide scale off the coast of Oregon and Washington.

Modern sounding data (also referred to as the 1998 data) include data from hydrographic surveys collected around Grays Harbor, Willapa Bay, and Columbia River mouth by the USACE (Table 2, Fig. 3). Some data were also constructed by the authors to ensure the smooth transitions between the historical and modern bathymetry (refer to the section Generating the Modern 1998 Hydrographic Data Set for a more complete discussion).

Shoreline files are included in SURFER .bln and ARC/INFO arc coverage formats for reference. The coastline files (orwanoaacst and swwanoaacst) were derived from NOAA medium resolution, 1:70,000, vector shorelines (NOAA,1994). The data file ORWANOAACST includes data revised between July 1989

and September 1991; the data file SWWANOAACST includes data revised between March 1991 and September 1991. 
Data were processed using both ARC/INFO (v. 7.1) and SURFER32 (v 6.0). Original NOS point data were projected from geographic units (latitude/longitude, datum NAD27) to the Washington State Plane South coordinate system (datum NAD83). Non-sounding data (cartographic code not equal to 711 ; rocks awash, pilings, etc.) and obviously erroneous or questionable data (based on contour *donuts*, trackline crossing inconsistencies, etc.) were edited out of the data set. USACE data for Grays Harbor and Willapa Bay were converted from Washington State Plane South (feet) and for the Columbia River from Oregon State Plane (feet). SURFER was used to generate preliminary grids of all the data. Data editing and final grid construction was completed using ARC/INFO.

Individual grids were processed using different data sets and gridding methodologies. Grid boundaries for the SWWA and ORWA grids are listed in Tables 3 and 4, respectively.

The SWWA26 grid was created by gridding three subsets of edited NOS point data (midshore; nearshore; shoreface; Fig. 2) using parameters that best fit the individual data set. Subset boundaries were determined based on differences in the original 1926 survey scale, sounding distribution, and data precision (see Gibbs and Gelfenbaum, 1999 for a more detailed description). Each subset was gridded separately in SURFER, using the processing steps outlined in Table 5, then imported into ARC/INFO, clipped to its specific boundary, and merged with the other sub-grids to create the final SWWA26 surface.

The SWWA98 grid is the SWWA26 grid with a subset of merged and gridded 1926/1998 point data nested within it. The merged 1926/1998 point data set includes both the 1998 USACE hydrographic data from the approaches to and ebb-tidal deltas of Grays Harbor, Willapa Bay, and the Columbia River, and portions of the 1926 NOS hydrographic data set. Because of large changes that have occurred in the location and morphology of these ebb-tidal deltas since 1926, the merged data have, in places, abrupt and irregular boundaries. In order to obtain a smooth transition across the survey boundaries, data was edited, modified, and, where necessary, point data added, based on inferred shoreface and ebb-tidal delta morphology. This modified and merged 1926/1998 data set was then gridded, clipped to the modified 1998 survey boundaries, and mosaicked with SWWA26 to produce the final SWWA98 surface. Specific techniques used to create the merged 1926/1998 point data set are discussed in the following section Generating The Modern 1998 Hydrographic Data Set. Specific grid processing parameters used to create SWWA98 are shown in Table 6.

The ORWA grids include gridded raw, unedited NOS hydrographic data with the more rigorously edited and processed SWWA grids nested within them. The NOS point data were gridded using a linear kriging algorithm, matrix smoothed, and mosaicked with either the SWWA26 or SWWA98 grid to create the final ORWA26 and ORWA98 surfaces, respectively. Specific processing parameters are shown in Table 7. 


\section{GENERATING THE MODERN 1998 HYDROGRAPHIC DATA SET}

The discussion below describes the techniques employed to create the merged 1926/1998 hydrographic data set for the Columbia River, Willapa Bay, and Grays Harbor. The individual sections describe the data that were collected, any problems that were identified when combining the 1926 and 1998 data sets, and finally the specific modifications made to the original data to generate smooth transitions between the merged data sets. Although this work gives a reasonable estimate of the modern seafloor morphology, the user is cautioned to only use this data set with full knowledge of the original intent (wave modeling experiments), the limitations, and assumptions used to generate it. The data should not be used for navigational purposes.

\section{COLUMBIA RIVER}

Data collection and final results:

The Portland District USACE collected single channel echosounder surveys at the entrance and approaches to the Columbia River during the summer of 1998 (Fig. 4). Data from the two northernmost lines were not included because of anomalously deep (1 to 3-m deeper) values. Contours generated from the final merged and edited 1926/1998 data are shown in Figure 5.

Comparison between 1926 and 1998 data:

Contours generated from the merged but not edited 1926 and 1998 data set show a generally smooth transition between the two data sets across the northern boundary (Fig. 6). No additional data editing or processing was applied in this area. Across the southern boundary, however, the 1926 contours are dramatically skewed offshore relative to the 1998 contours (up to 350-m near 20-m water depth, with less offset in shallower and deeper water; Fig. 7a). The large offset in the contours across this boundary suggests dramatic steepening of the shoreface and nearshore between 1926 and 1998. This offset may also be enhanced as a result of registration and surveying errors within the 1926 survey set as discussed in Gibbs and Gelfenbaum (1999).

\section{Data Modification:}

To smooth the offset across the southern boundary of the 1926/1998 data set, an approximately $10-\mathrm{km} \times 5-\mathrm{km}$ polygon of 1926 data was deleted and thirty-four linear contours between 11-m and 50-m water depth were added (Fig. 7b). The size of the polygon was selected to eliminate the sharp or angular transition between the two data sets (Fig. 7c). The 1926 contours portray the offshore morphology in this area as sinuous (Fig. 7a). In contrast, contours generated by the merged 1926/1998 data are more linear.

\section{WILLAPA BAY}

Data collection and results:

The Seattle District USACE, in conjunction with the USACE Waterways Experiment Station (Vicksburg Mississippi), collected single-channel echosounder surveys and high density SHOALS LIDAR surveys at the entrance to Willapa Bay during the summer of 1998 (Fig. 8). The original data set was clipped to include only data seaward of the inlet and any overlapping points were eliminated. Contours of merged and edited 1926/1998 data are shown in Figures 8 and 9c.

Comparison between 1926 and 1998 data:

The position of the Willapa Bay ebb-tidal delta migrated about 4.5-km northwestward between 1926 and 1998. Unfortunately, the 1998 USACE hydrographic survey did not cover the 
northern nor seaward extent of the entire ebb-tidal delta (Fig. 9a). In order to obtain a reasonable modern ebb-tidal delta surface, considerable data manipulation was required. The resulting data set should be considered an interim "best guess" and should not be used for any rigorous analysis.

\section{Data Modification:}

To generate a complete data set for the 1998 Willapa Bay ebb-tidal delta surface, data from the 1926 Willapa Bay ebb-tidal delta were shifted 4496-m northeast (from 221741.698 158005.741 to 222091.341162488 .038 ; a total of $4495.917-\mathrm{m}$ ) so that the $-10 \mathrm{~m}$ contour from both 1926 and 1998 ebb-tidal deltas coincided. These data were then rotated 4 degrees counterclockwise around the center of the ebb-tidal shield (223394.744 157290.476) such that the rotated shoreface contours became coincident with the non-rotated 1926 contours north of the ebb-tidal delta. This "shifted" data set was added to the 1998 USACE data to create the northern boundary of the Willapa Bay ebb-tidal delta (Fig. 9b). Offshore and to the south of the 1998 ebbtidal delta, six contours were added, at 5-m intervals, between 10-m and 40-m, in order to generate an outer edge of the delta, and a smooth transition with the 1926 contours to the south (Fig. 9b).

The results of the process described above are shown as contours in Figure 9c. The final results are poor. The seaward edge of the delta is likely too steep and the northern edge remains problematic. Multibeam surveys collected during the summer of 1999 by the Southwest Washington Coastal Erosion Study (Flood et al., 2000) cross the outer edges of the Willapa Bay ebb-tidal delta and will help constrain the morphology of this feature. Those data will be included in any future versions of this data release.

\section{GRAYS HARBOR}

\section{Data collection and results:}

The Seattle District USACE collected single-channel echosounder surveys at the entrance and approaches to Grays Harbor during the summer of 1998 (Fig. 10). Six overlapping survey tracklines were collected south of the inlet. Sounding data from lines collected from west to east are not included here, as they seem to impart some error to the results. Contours of merged and edited 1926/1998 data are presented in Figure 11.

\section{Comparison between 1926 and 1998 data:}

Contours generated from the merged 1926 and 1998 data set show a generally smooth transition between the two data sets across the southern boundary (Fig. 12). No additional data editing or processing was applied in this area. Across the northern boundary, the 1926 contours are offset shoreward relative to the 1998 contours between 0 and $\sim 12-\mathrm{m}$ water depth (Fig. 13a). The offset in contours across this boundary suggests shoaling and deposition of material on the shoreface between 1926 and 1998. The difference may also be enhanced as a result of registration and surveying errors within the 1926 survey set as discussed in Gibbs and Gelfenbaum, 1999.

\section{Data Modification:}

To smooth the offset across the northern boundary of the 1926/1998 data set, an approximately $3.5-\mathrm{km} \times 7-\mathrm{km}$ polygon of 1926 data was deleted and four linear contours were added at 6-m, 8-m, 10-m, and 12-m water depth (Fig. 13b). The shape of the polygon and the length and orientation of the added contours were constrained by the requirement that the transition between the 1998 and 1926 contours were smooth and essentially linear (Fig. 13c). 
The following section describes the data directory file structure of the accompanying CDROM, the geographic format of the data, and the differences between SURFER and ARC/INFO grid formats.

\title{
DATA DIRECTORY FILE STRUCTURE
}

\author{
1_README.TXT Simple overview of data structure \\ version_history.txt OFR version history \\ OFR00-448.pdf This document in Adobe Acrobat .pdf format \\ Acrobat \\ gzip: \\ Adobe Acrobat Reader 4.0; tool for reading .pdf document (PC, MAC) \\ Tools for unzipping data files (PC, UNIX, and MAC) \\ stateplane: \\ Data in Washington State Plane South (Zone 5626; NAD83) coordinates \\ utm: \\ Data in UTM Zone 10 (NAD83) coordinates \\ Subdirectories within both stateplane and utm directories include: \\ grids: \\ contours: \\ shorelines: \\ pointdata: \\ conversions: \\ metadata: \\ Bathymetric surface grids \\ *.e00 ARC/INFO export files \\ *asc ARC/INFO ASCII grids \\ *.grd SURFER ASCII grids \\ *.dat ASCII XYZ coordinates \\ 1 meter bathymetry contours; ARC/INFO export files only \\ NOS composite shoreline for ORWA and SWWA areas \\ *.e00 ARC/INFO export files \\ *.bln SURFER blanking file \\ Hydrographic sounding data \\ .e00 ARC/INFO point coverages \\ .dat ASCII data \\ Conversion programs and useful files \\ FGDC formal metadata \\ *.txt ASCll text \\ *.faq html "frequently asked questions" format \\ *.html html format
}

\section{GEOGRAPHIC FORMAT}

\begin{tabular}{lll} 
& UTM & WASP \\
\cline { 2 - 2 } Horizontal datum: & NAD83 & NAD83 \\
Vertical datum: & MLLW meters & MLLW meters \\
Projection: & UTM Zone 10 & Washington State Plane South Zone 5626 \\
Ellipsoid: & GRS 1980 & GRS 1980
\end{tabular}




\section{GRID FORMAT: SURFER vs. ARC/INFO}

The SURFER and ARC/INFO programs read ASCII gridded data in slightly different formats. SURFER uses a node-based, mesh grid format with values at the nodes. ARC/INFO uses a cellbased raster grid format with values at the center of the grid cells. Both formats have the same total number of columns and rows, and the coordinates of the data values are coincident. However, the boundaries defined by gridded data in the two formats differ. Xmin and ymin values of ARC/INFO grids are offset $-1 / 2$ cell-size (dx,dy) relative to SURFER grids, while ARC/INFO xmax and ymax values are $1 / 2 d x$, dy greater. The row-column origin also differs between the two formats. The row-column origin is the lower left corner in SURFER and the upper left corner in ARC/INFO.

\section{For example:}

For the same size grid ( $4 \times 3$; same total number of data points), the ARC/INFO grid origin (xmin, ymin) is $1 / 2 \mathrm{dx}$, dy smaller than the same Surfer grid. The maximum extent (xmax, ymax) is $1 / 2 \mathrm{dx}$,dy greater.

$4 \times 3$ Node based mesh grid (Surfer)

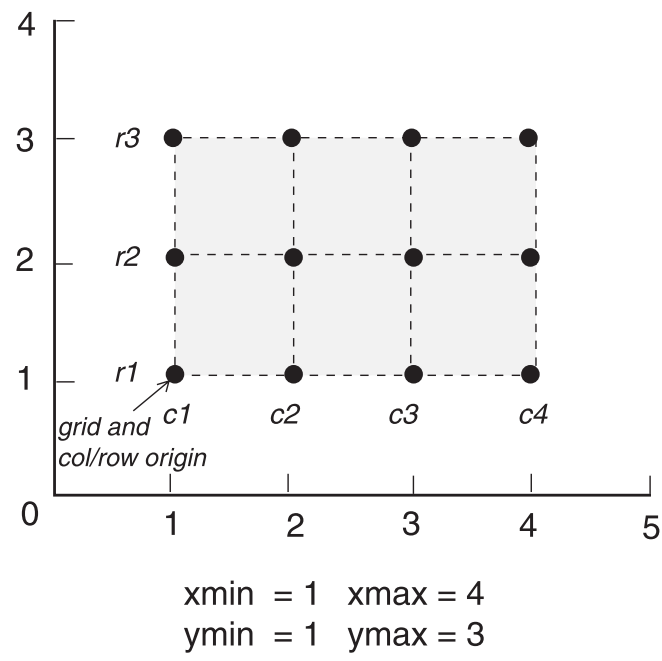

$4 \times 3$ Cell based raster grid (Arclnfo)

These differences in data format require that the grids be flipped and headers modified when converting between the two formats. Two programs have been written to achieve this: The FORTRAN program arc2grd transposes ARC/INFO ASCII gridded data ( ${ }^{*}$.asc files) into SURFER ASCII gridded data (*.grd files). The Arc Macro Language (AML) application importsurfergrids.aml imports SURFER *.grd files into ARC/INFO.

\section{Header Formats}

SURFER ASCIl header format ( ${ }^{*}$.grd)

DSAA

nrow ncol

xmin ymin

$x \max y \max$

zmin zmax

line format $=10$ numbers per line

followed by $a<C R>$

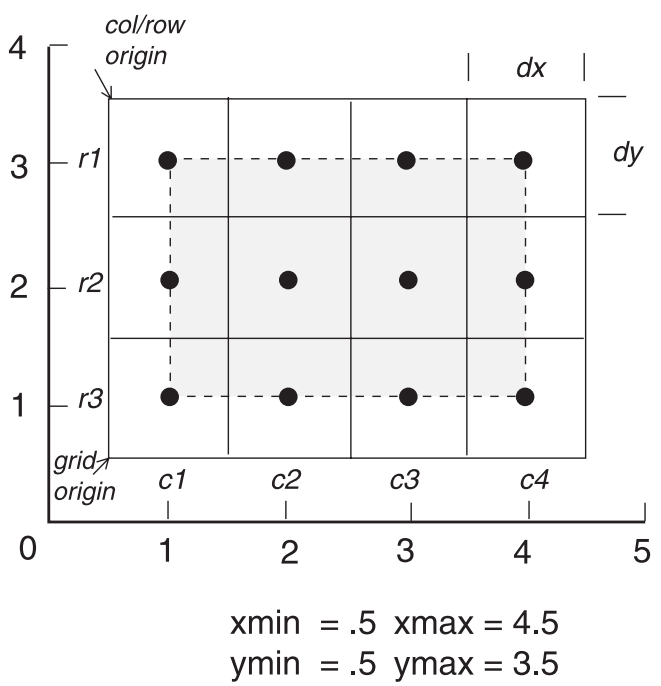

$x \min =.5 \quad x \max =4.5$

$y \min =.5 y \max =3.5$ 
Table 1. NOS hydrographic surveys included in the Oregon-Washington (ORWA) data sets

\begin{tabular}{|c|c|c|}
\hline $\begin{array}{c}\text { USC\&GS } \\
\text { Survey_Year }\end{array}$ & NGDC Number & LOCATION \\
\hline H5069_1930 & 03001002 & Northern Washington; shoreface \\
\hline H5108_1930 & 03631003 & Northern Washington; shoreface \\
\hline H5107_1930 & 03631002 & Northern Washington; shoreface \\
\hline H4716_1927* & 03NG1148 & Central Washington; shoreface \\
\hline H4715_1927* & 03NG1147 & Central Washington; shoreface \\
\hline H4710_1927* & $03 N G 1021$ & Central Washington; shoreface \\
\hline H4621_1926* & 03NG1015 & Willapa Bay; shoreface \\
\hline H4658_1928* & 03NG1020 & Willapa Bay; shoreface \\
\hline H4620_1926* & 03NG1142 & Willapa Bay; shoreface \\
\hline H4619_1926* & 03NG1014 & Washington; shoreface \\
\hline H4618_1926* & 03NG1296 & Columbia River mouth; shoreface \\
\hline H4611_1926* & 03NG1342 & Northern Oregon; shoreface \\
\hline H4612_1926* & 03NG1012 & Northern Oregon; shoreface \\
\hline H4613_1926 & 03NG1013 & Southern Oregon; shoreface \\
\hline H8346_1956 & 03F11531 & Southern Oregon; shoreface; 1926 survey missing \\
\hline H8370_1957 & 03F11534 & Southern Oregon; shoreface; 1926 survey missing \\
\hline H4745_1927 & $03 N G 1023$ & Southern Oregon; shoreface \\
\hline H4746_1927 & 03NG1024 & Southern Oregon; shoreface \\
\hline H4747_1927 & 03NG1025 & Southern Oregon; shoreface \\
\hline H4748_1927 & $03 N G 1026$ & Southern Oregon; shoreface \\
\hline H4878_1928 & $03 N G 1213$ & Southern Oregon \\
\hline H4878a_1928 & 03NG1214 & Southern Oregon; shoreface \\
\hline H4749_1927 & 03NG1027 & Southern Oregon; shoreface \\
\hline H4879_1928 & 03NG1234 & Southern Oregon; shoreface \\
\hline H4880_1928 & 03NG1033 & Southern Oregon; shoreface \\
\hline H4881_1928 & 03NG1034 & Southern Oregon; shoreface \\
\hline H4884_1928 & 03NG1037 & Southern Oregon; shoreface \\
\hline H5110_1930 & 03631005 & Washington; nearshore \\
\hline H5068_1930 & 03631001 & Washington; nearshore \\
\hline H4729_1927* & 03NG1149 & Washington; nearshore \\
\hline H4728_1927* & 03NG1022 & Washington; nearshore \\
\hline H4634_1927* & 03NG1016 & Oregon/Washington; nearshore \\
\hline H4635_1926* & 03NG1017 & Northern Oregon; nearshore \\
\hline H4637_1926 & 03NG1145 & Southern Oregon; nearshore \\
\hline H4755_1927 & 03NG1028 & Southern Oregon; nearshore \\
\hline H4756_1927 & 03NG1029 & Southern Oregon; nearshore \\
\hline H4882_1928 & 03NG1035 & Southern Oregon; nearshore \\
\hline H4883_1928 & 03NG1036 & Southern Oregon; nearshore \\
\hline H4894_1928 & 03NG1044 & Southern Oregon; nearshore \\
\hline H9413_1974 & 03121083 & Northern Washington; mid-offshore; overlaps with H5114 \\
\hline H9418_1974 & 03121084 & Northern Washington; mid-offshore; overlaps with H5114 \\
\hline H5114_1930 & 03631073 & Northern Washington; mid-offshore \\
\hline H4735_1927* & $03 N G 1226$ & Washington; mid-offshore \\
\hline H4633a_1926* & $03 N G 1143$ & Oregon/Washington; midshore \\
\hline H4636_1926* & 03NG1018 & Northern Oregon; midshore \\
\hline H4638_1926 & $03 N G 1146$ & Southern Oregon; midshore \\
\hline H4754_1927 & $03 N G 1211$ & Southern Oregon; midshore \\
\hline H4758_1927 & 03NG1151 & Southern Oregon; midshore \\
\hline H4895_1928 & 03NG1217 & Southern Oregon; mid- shore \\
\hline H4896a__1928 & 03NG1215 & Southernmost Oregon; mid -shore \\
\hline H4775_1927 & 03NG1031 & Washington; offshore \\
\hline H4633b_1926 & 03NG1144 & Oregon/Washington; offshore \\
\hline H4639_1926 & 03NG1019 & Northern Oregon; offshore \\
\hline H4753_1927 & 03NG1150 & Southern Oregon; offshore \\
\hline H4757_1927 & 03NG1030 & Southern Oregon; offshore \\
\hline H4888_1928 & 03NG1040 & Southern Oregon; offshore \\
\hline
\end{tabular}


Table 2. NOS and USACE surveys in the Southwest Washington (SWWA) data sets

\begin{tabular}{lcl}
\hline USC\&GS Survey_Year & NGDC Number & \multicolumn{1}{c}{ LOCATION } \\
\hline H4716_1927 & O3NG1148 & Central Washington; shoreface \\
H4715_1927 & O3NG1147 & Central Washington; shoreface \\
H4710_1927 & O3NG1021 & Central Washington; shoreface \\
GH98ANP* & USACE & Grays Harbor mouth and approaches \\
H4621_1926 & 03NG1015 & Willapa Bay; shoreface \\
H4658_1928 & O3NG1020 & Willapa Bay; shoreface \\
WB98COE* & USACE & Willapa Bay and ebb tidal delta \\
H4620_1926 & 03NG1142 & Willapa Bay; shoreface \\
H4619_1926 & O3NG1014 & Washington; shoreface \\
PCOE98* & USACE & Columbia River mouth and approaches \\
H4618_1926 & 03NG1296 & Columbia River mouth; shoreface \\
H4611_1926 & O3NG1342 & Northern Oregon; shoreface \\
H4612_1926 & O3NG1012 & Northern Oregon; shoreface \\
H4729_1927 & O3NG1149 & Washington; nearshore \\
H4728_1927 & 03NG1022 & Washington; nearshore \\
H4634_1927 & 03NG1016 & Oregon/Washington; nearshore \\
H4635_1926 & 03NG1017 & Northern Oregon; nearshore \\
H4735_1927 & 03NG1226 & Washington; mid-offshore \\
H4633a_1926 & O3NG1143 & Oregon/Washington; midshore \\
H4636_1926 & O3NG1018 & Northern Oregon; midshore \\
\hline
\end{tabular}

Table 3. Boundaries of SWWA grids

\begin{tabular}{|l|c|c|}
\hline & UTM & WA State Plane South \\
\hline FINAL GRIDS & $\begin{array}{l}\text { swwa26_500utm } \\
\text { swwa26_750utm }\end{array}$ & $\begin{array}{l}\text { swwa26_500sp } \\
\text { swwa26_750sp }\end{array}$ \\
\hline $500 \mathrm{~m}$ grid & 93 columns by 327 rows & 117 columns by 324 rows \\
\hline $750 \mathrm{~m}$ grid & 62 columns by 218 rows & 78 columns by 216 rows \\
\hline
\end{tabular}

SURFER grid boundaries

\begin{tabular}{|c|c|c|c|c|}
\hline \multirow[t]{2}{*}{$500 \mathrm{~m} \mathrm{grid}$} & $x \min : 382500$ & xmax: 428500 & xmin: 190000 & xmax: 248000 \\
\hline & ymin: 5081500 & $y \max : 5244500$ & ymin: 67000 & ymax: 228500 \\
\hline \multirow[t]{2}{*}{$750 \mathrm{~m}$ grid } & $x \min : 382500$ & xmax: 428250 & xmin: 190000 & xmax: 247750 \\
\hline & ymin: 5081500 & ymax: 5244250 & ymin: 67000 & ymax: 228250 \\
\hline
\end{tabular}

ARC/INFO grid boundaries

\begin{tabular}{|c|c|c|c|c|}
\hline \multirow{2}{*}{$500 \mathrm{~m}$ grid } & xmin: 382250 & xmax: 428750 & xmin: 189750 & $x \max : 248250$ \\
\hline & ymin: 5081250 & ymax: 5244750 & ymin: 66750 & ymax: 228750 \\
\hline $750 \mathrm{~m}$ grid & xmin: 382125 & xmax: 428625 & xmin: 189625 & xmax: 248125 \\
\hline & ymin: 5081125 & ymax: 5244625 & ymin: 66625 & ymax: 228625 \\
\hline
\end{tabular}


Table 4. Boundaries of ORWA grids

\begin{tabular}{|c|c|c|}
\hline & UTM & WA State Plane South \\
\hline FINAL GRIDS & $\begin{array}{l}\text { orwa26_500utm } \\
\text { orwa26_750utm } \\
\text { orwa98_500utm } \\
\text { orwa98_750utm }\end{array}$ & $\begin{array}{l}\text { orwa26_500sp } \\
\text { orwa26_750sp } \\
\text { orwa98_500sp } \\
\text { orwa98_750sp }\end{array}$ \\
\hline $500 \mathrm{~m}$ grid & 198 columns by 885 rows & 243 columns by 891 rows \\
\hline $750 \mathrm{~m}$ grid & 132 columns by 590 rows & 162 columns by 594 rows \\
\hline
\end{tabular}

SURFER grid boundaries

\begin{tabular}{|c|c|c|c|c|}
\hline $500 \mathrm{~m}$ grid & xmin: 330000 & xmax: 428500 & xmin: 127000 & xmax: 248000 \\
\hline & $y \min : 4875000$ & ymax: 5317000 & ymin: -135500 & ymax: 309500 \\
\hline $750 \mathrm{~m}$ qrid & 330000 & 428250 & xmin: 127000 & \\
\hline & ymin: 4875000 & ymax: 5316750 & ymin: -135500 & ymax: 309250 \\
\hline
\end{tabular}

ARC/INFO grid boundaries

\begin{tabular}{|l|lll|lll|}
\hline 500m grid & xmin: 329750 & xmax: 428750 & xmin: 126750 & xmax: 248250 \\
\hline & ymin: 4874750 & ymax: 5317250 & ymin: -135750 & ymax: 309750 \\
\hline 750m grid & xmin: 329625 & xmax: 428625 & xmin: 126625 & xmax: 248125 \\
\hline & ymin: 4874625 & ymax: 5316750 & ymin: -135875 & ymax: 309625 \\
\hline
\end{tabular}

Table 5. Processing steps used to create the SWWA26 grid

\begin{tabular}{|c|c|c|}
\hline Projection & UTM & WA State Plane \\
\hline FINAL GRIDS & $\begin{array}{l}\text { swwa26_500utm } \\
\text { swwa26_750utm }\end{array}$ & $\begin{array}{l}\text { swwa26_500sp } \\
\text { swwa26_750sp }\end{array}$ \\
\hline $\begin{array}{l}\text { SUB-GRIDS } \\
\text { Data Source }\end{array}$ & swwa26pts_utm & swwa26pts_sp \\
\hline $\begin{array}{l}\text { MIdshore } \\
\text { Processing } \\
\text { techniques }\end{array}$ & $\begin{array}{l}\text { 1. Clip points to midshore window } \\
\text { 2. Gaussian krig data using: } \\
C=1720 ; L=83400 ; \text { nugget }=0.1 \text {; } \\
\text { search radius }=25000\end{array}$ & $\begin{array}{l}\text { 1. Clip points to midshore window } \\
\text { 2. Gaussian krig data using: } \\
\text { SURFER defaults (except nugget) } \\
C=3560 ; L=90100 \text {; nugget }=2\end{array}$ \\
\hline $\begin{array}{l}\text { Nearshore } \\
\text { Processing } \\
\text { techniques }\end{array}$ & $\begin{array}{l}\text { 1. Clip points to nearshore window } \\
\text { 2. Gaussian krig data using: } \\
C=617 ; L=20000 ; \text { nugget }=2.1 \text {; } \\
\text { search radius }=20000\end{array}$ & $\begin{array}{l}\text { 1. Clip points to nearshore window } \\
\text { 2. Gaussian krig data using: } \\
\text { SURFER Defaults. } C=458 \text {; } \\
L=87300\end{array}$ \\
\hline $\begin{array}{l}\text { Shoreface } \\
\text { Processing } \\
\text { techniques }\end{array}$ & $\begin{array}{l}\text { 1. Clip points to shoreface window } \\
\text { 2. Gaussian krig data using: } \\
C=110 ; L=83500 ; \text { nugget }=0.09 ; \\
\text { search radius }=20000\end{array}$ & $\begin{array}{l}\text { 1. Clip points to shoreface window } \\
\text { 2. Gaussian krig data using: } \\
C=110 ; L=83500 ; \text { nugget }=0.09 ; \\
\text { search radius }=20000\end{array}$ \\
\hline$\underline{\text { All sub-grids }}$ & $\begin{array}{l}\text { 3. Import gridded data to } \\
\text { ARC/INFO, clip to sub-grid } \\
\text { boundary and mosaic. }\end{array}$ & $\begin{array}{l}\text { 3. Import gridded data to } \\
\text { ARC/INFO, clip to sub-grid } \\
\text { boundary and mosaic. }\end{array}$ \\
\hline
\end{tabular}


Table 6. Processing steps used to create the SWWA98 grid

\begin{tabular}{|c|c|c|}
\hline Projection & UTM & WA State Plane \\
\hline \multirow[t]{2}{*}{ FINAL GRIDS } & swwa98_500utm & swwa98_500sp \\
\hline & swwa98_750utm & swwa98_750sp \\
\hline Data source & nest98pts_utm & nest98pts_sp \\
\hline \multirow[t]{4}{*}{$\begin{array}{l}\text { Processing } \\
\text { techniques }\end{array}$} & $\begin{array}{l}\text { 1. Gaussian krig data using: } \\
C=1020 ; L=93000 ; \text { nugget }=0.1 \\
\text { search radius }=30000\end{array}$ & $\begin{array}{l}\text { 1. Gaussian krig data using: } \\
C=197 ; L=67800 ; \text { nugget }=0.1 ; \\
\text { search radius }=30000\end{array}$ \\
\hline & 2. Import gridded data to ARC & 2. Import gridded data to $A R C$ \\
\hline & 3. Erase areas of 1998 data & 3. Erase areas of 1998 data \\
\hline & 4. Merge with swwa26_(cellsize)utm & 4. Merge with swwa26_(cellsize)sp \\
\hline
\end{tabular}

Table 7. Processing steps used to create ORWA grids

\begin{tabular}{|c|c|c|}
\hline Projection & UTM & WA State Plane \\
\hline FINAL GRIDS: & $\begin{array}{l}\text { orwa26_500utm } \\
\text { orwa26_750utm } \\
\text { orwa98_500utm } \\
\text { orwa98_750utm }\end{array}$ & $\begin{array}{l}\text { orwa26_500sp } \\
\text { orwa26_750sp } \\
\text { orwa98_500sp } \\
\text { orwa98_750sp }\end{array}$ \\
\hline Data source & orwa26pts_utm* & orwa26pts_sp* \\
\hline \multirow[t]{3}{*}{$\begin{array}{l}\text { Processing } \\
\text { techniques }\end{array}$} & $\begin{array}{l}\text { 1. Linear kriging: } \\
\text { Using SURFER defaults (except } \\
\text { search radius) } \quad C=27100 ; A= \\
227000 ; \text { search radius }=25000^{\star \star}\end{array}$ & $\begin{array}{l}\text { 1. Linear kriging: } \\
\text { Using SURFER defaults (except search } \\
\text { radius) } C=38200 ; A=228000 \text {; search } \\
\text { radius }=25000^{\star *}\end{array}$ \\
\hline & $\begin{array}{l}\text { 2. Matrix smoothed: } \\
500 \mathrm{~m} \text { grid: } \\
\text { weight of matrix center }=2 \\
\text { number of rows on either side }=3 \\
\text { number of columns }=3 \\
750 \mathrm{~m} \text { grid: } \\
\text { weight of matrix center }=2 \\
\text { number of rows on either side }=2 \\
\text { number of columns }=2\end{array}$ & $\begin{array}{l}\text { 2. Matrix smoothed: } \\
500 \mathrm{~m} \text { grid: } \\
\text { weight of matrix center }=2 \\
\text { number of rows on either side }=3 \\
\text { number of columns }=3 \\
750 \mathrm{~m} \text { grid: } \\
\text { weight of matrix center }=2 \\
\text { number of rows on either side }=2 \\
\text { number of columns }=2\end{array}$ \\
\hline & $\begin{array}{l}\text { 3. SWWA area erased from large } \\
\text { ORWA grid and mosaicked with } \\
26 \text { or } 98 \text { SWWA grid }\end{array}$ & $\begin{array}{l}\text { 3. SWWA area erased from large } \\
\text { ORWA grid and mosaicked with } 26 \text { or } \\
98 \text { SWWA grid }\end{array}$ \\
\hline
\end{tabular}

*all NOS points within ORWA area (+1500m to account for smoothing) with cartographic code greater than -9999 (i.e. Sounding values are good)

** Pre-smoothed gridded boundary is $1500 \mathrm{~m}$ larger than final ORWA grid 

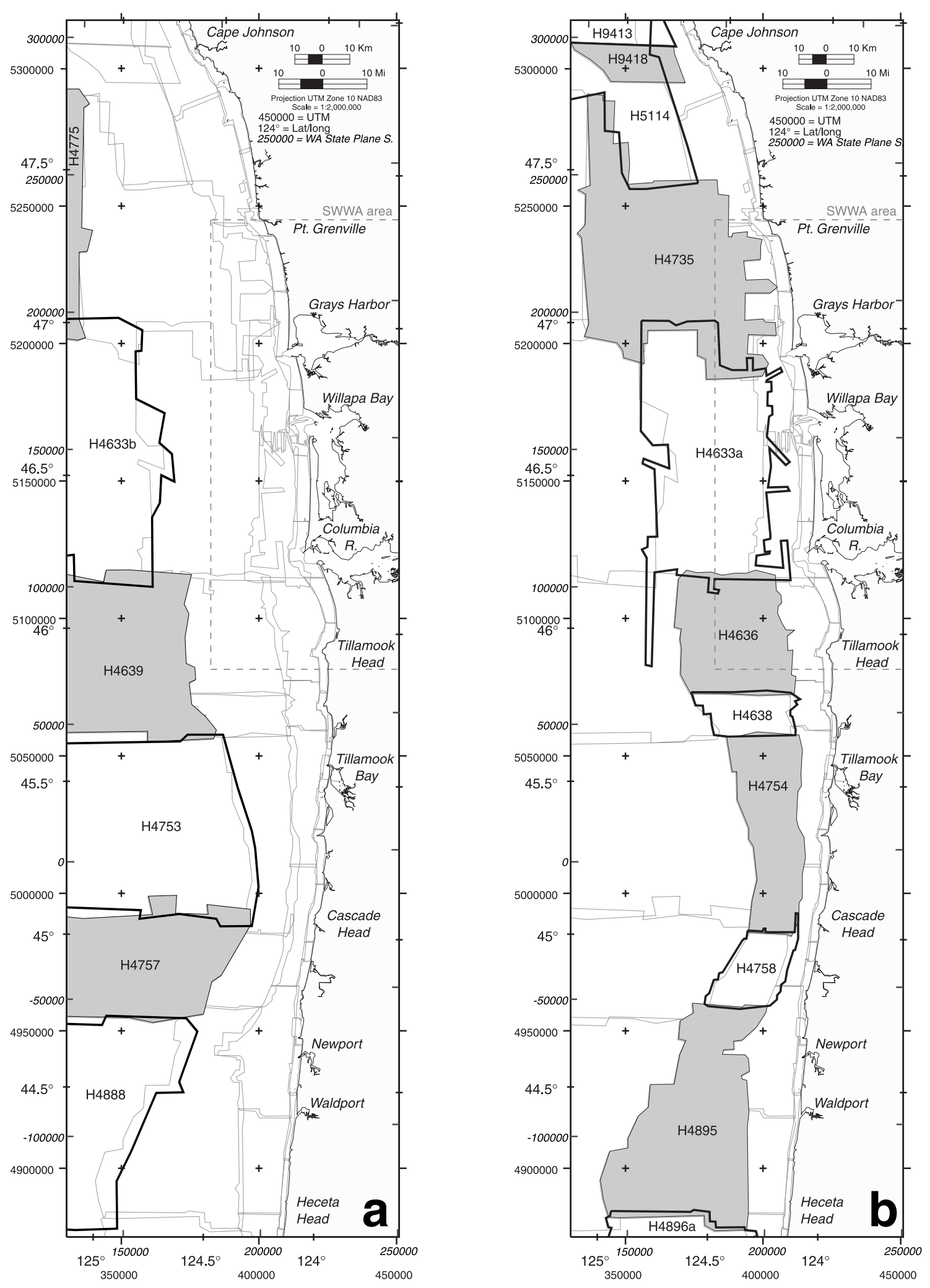

Figure 1a. NOS hydrographic surveys within the Oregon-Washington (ORWA) area. a) Off-shore surveys 1:120,000; b) Midshore surveys; 1:80,000 

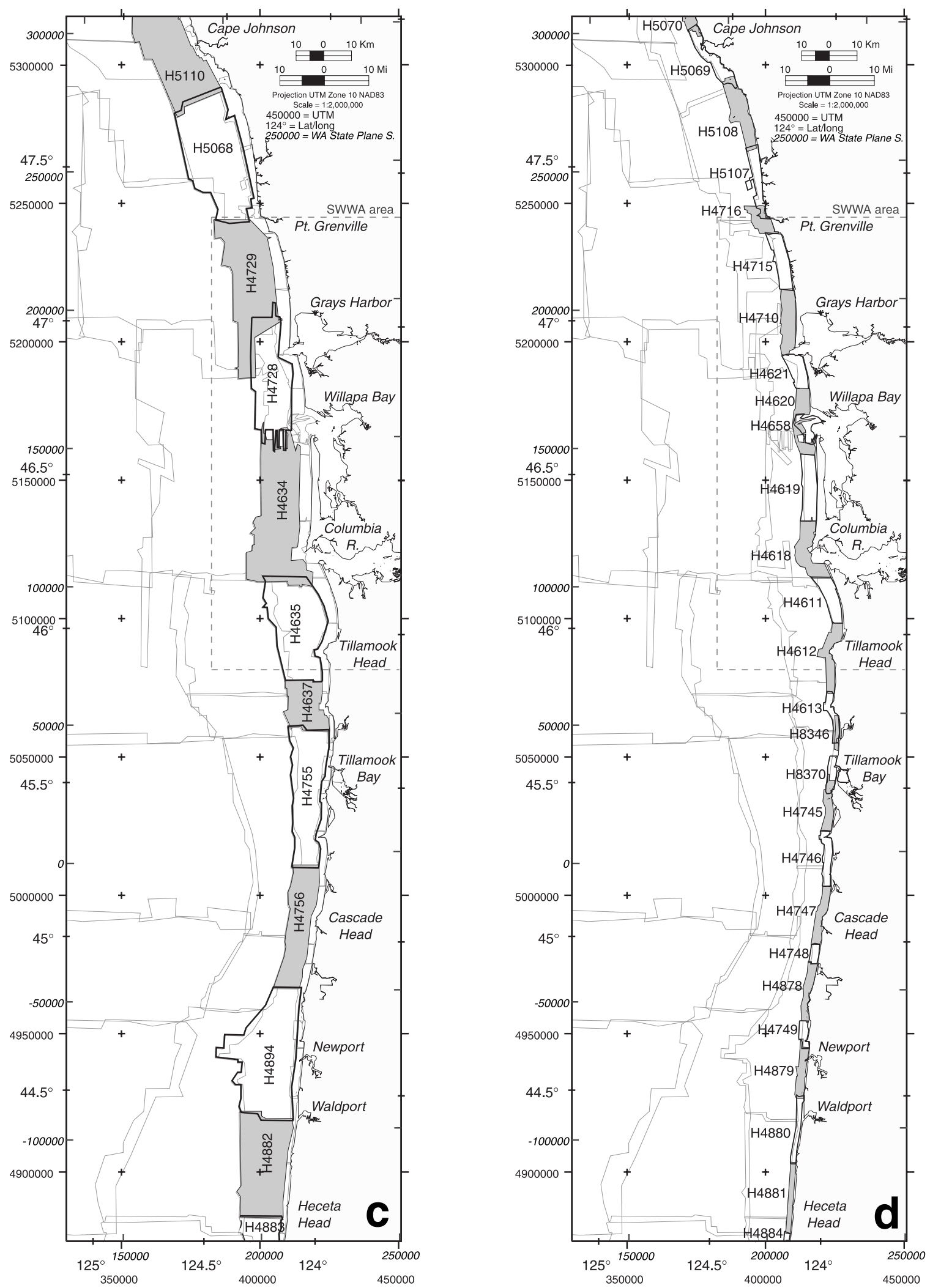

Figure 1b. NOS hydrographic surveys within the Oregon-Washington (ORWA) area. c) Nearshore surveys 1:40,000; d) Shoreface surveys; 1:20,000 


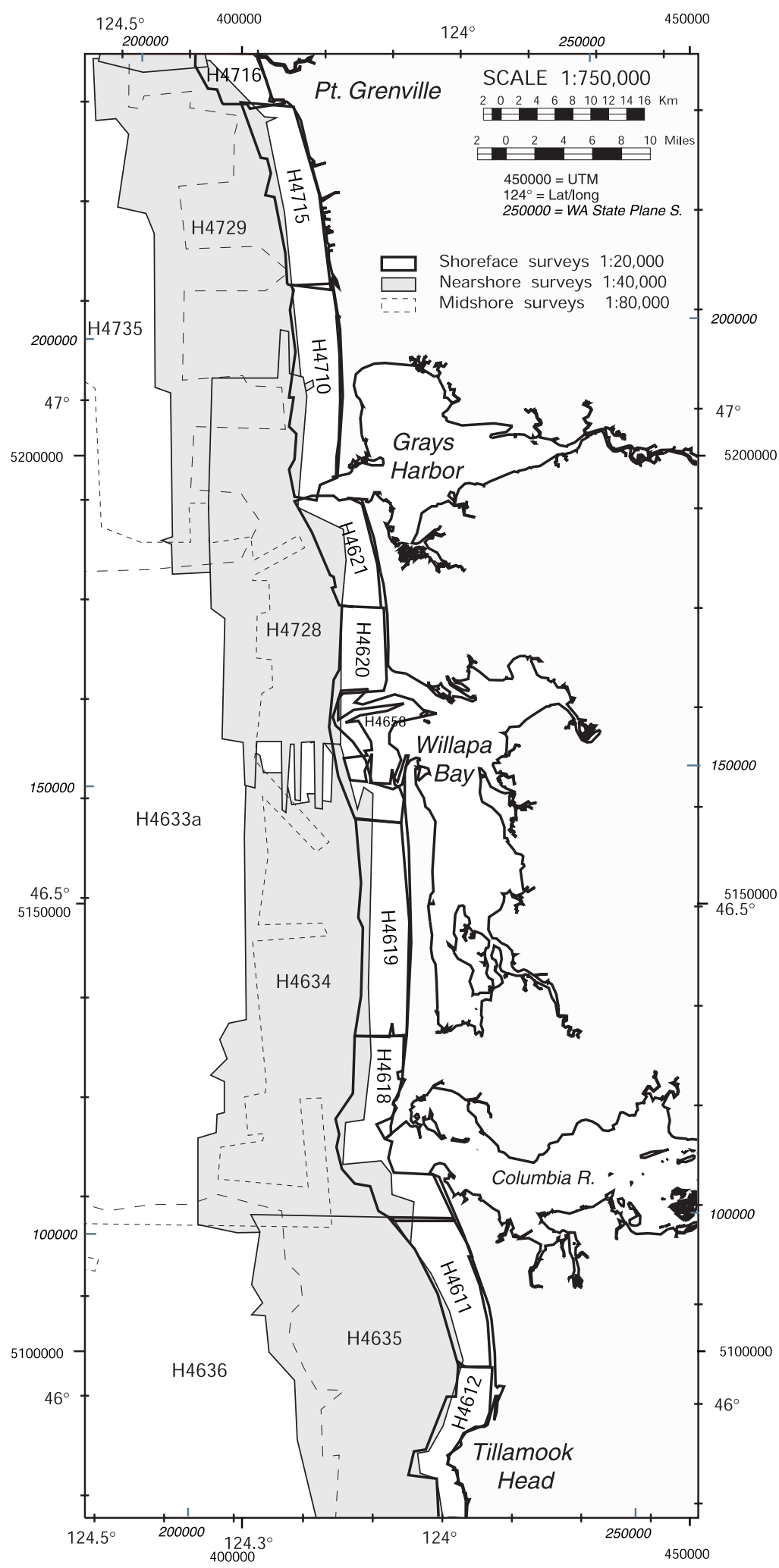

Figure 2. NOS hydrographic surveys within the Southwest Washington (SWWA) area. 


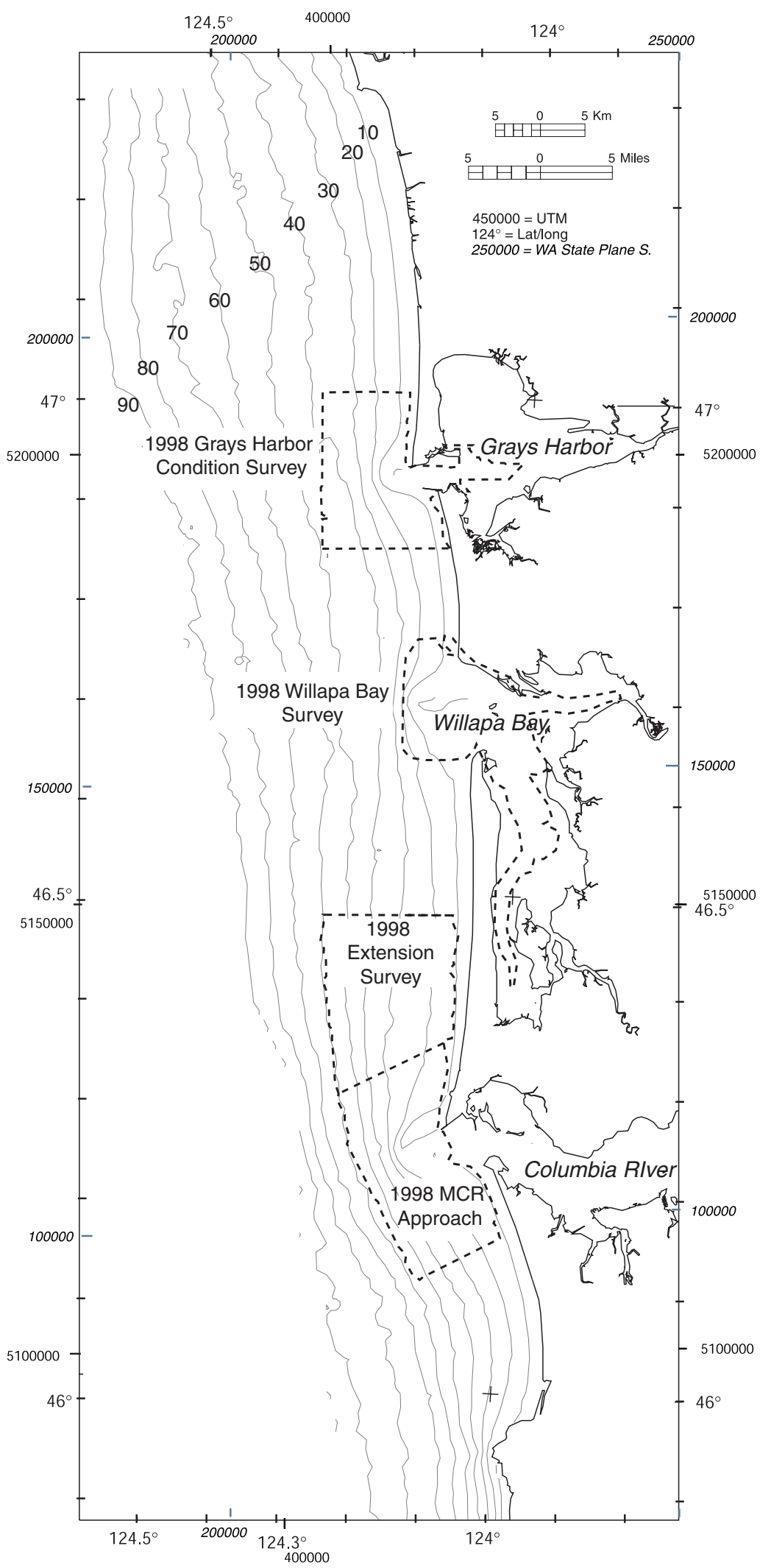

Figure 3. Boundaries of 1998 USACE hydrographic surveys. 


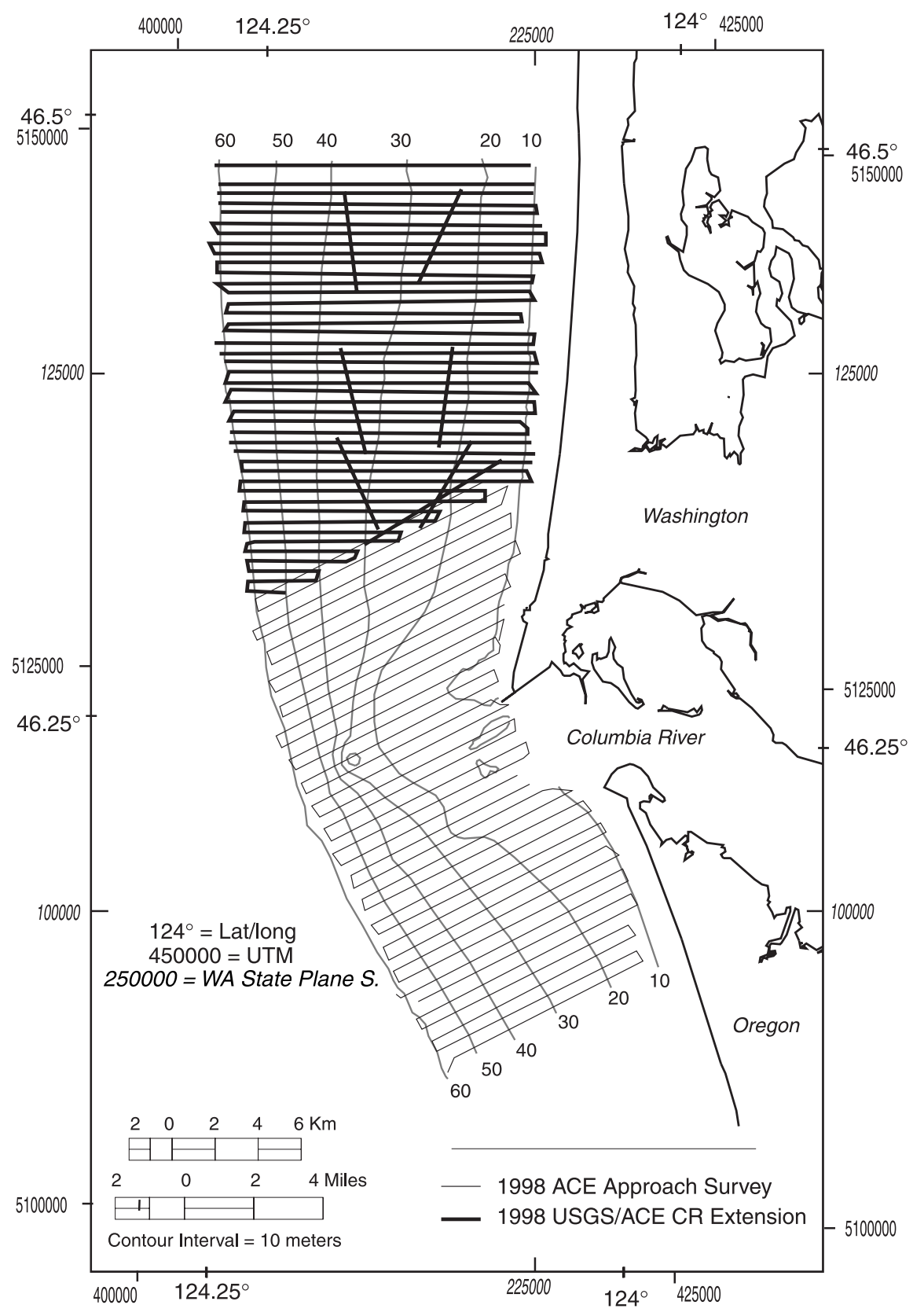

Figure 4. 1998 tracklines of Columbia River approach and extension surveys. Approach survey data courtesy of Portland District USACE. 


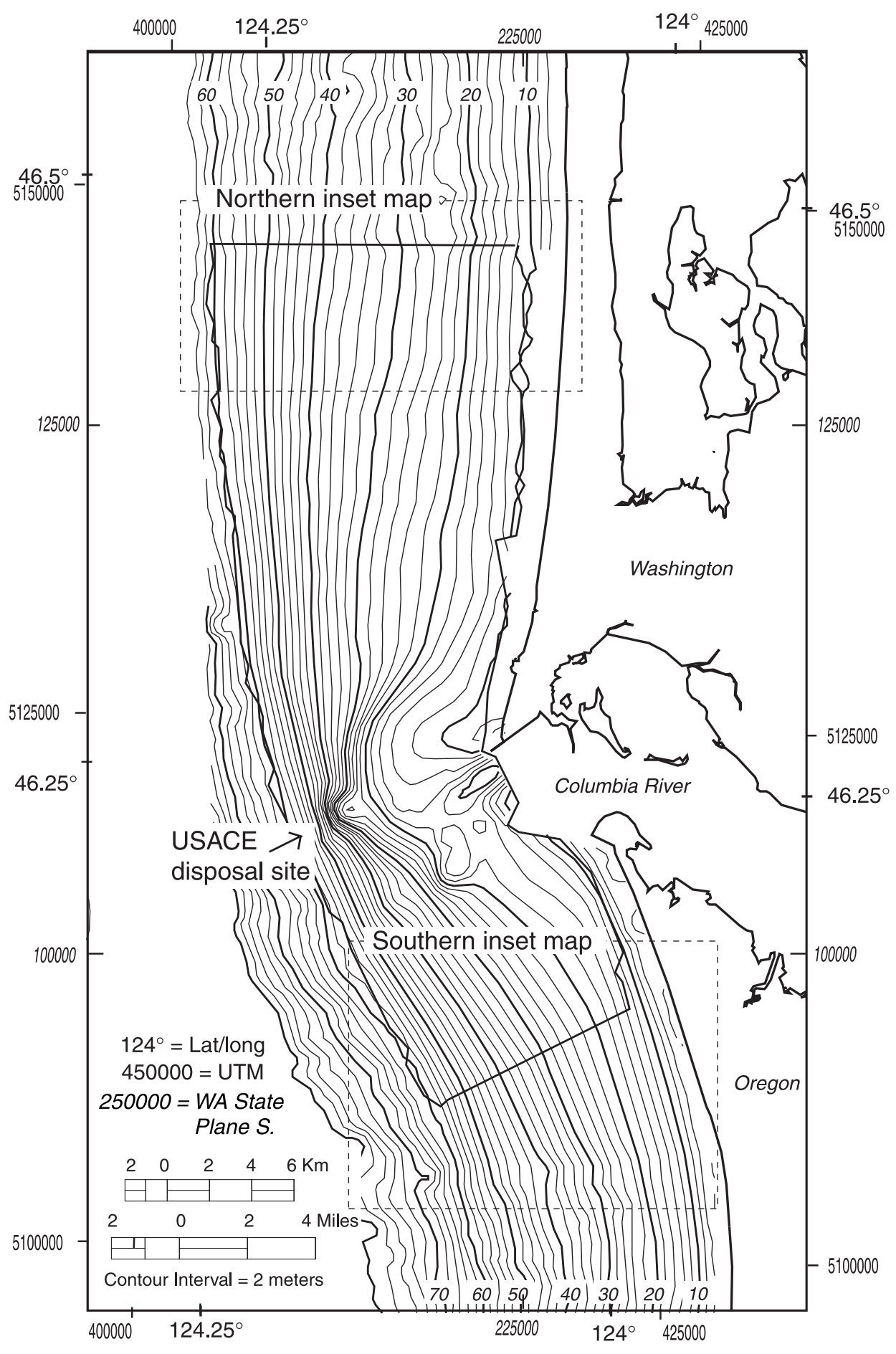

Figure 5. Bathymetric contours generated from edited and merged 1926/1998 data. 


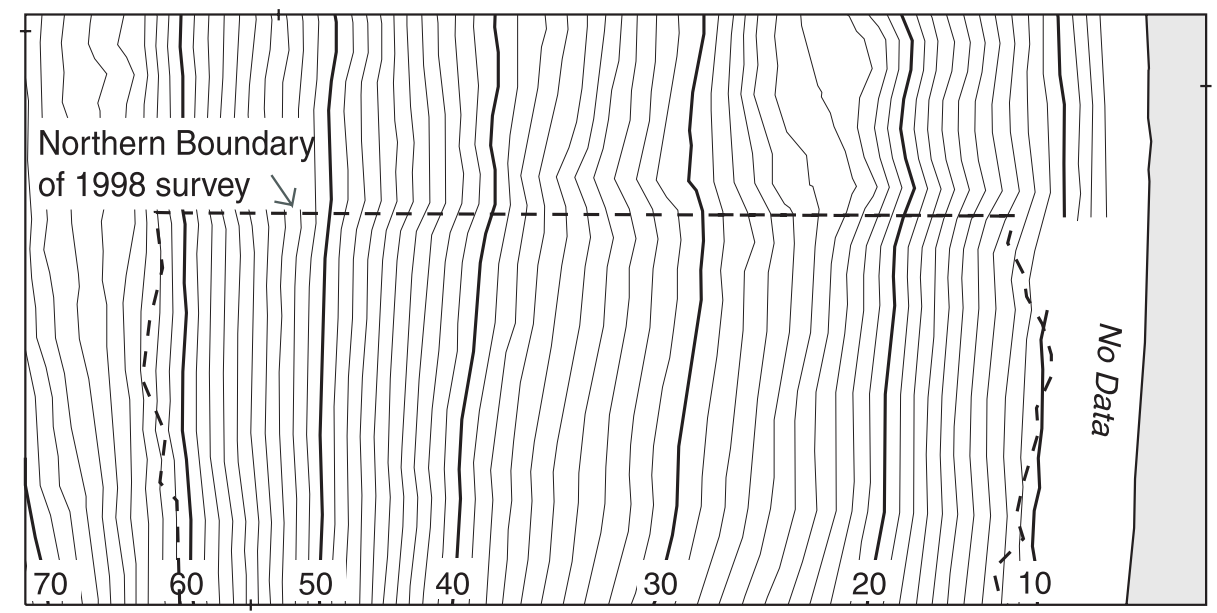

A. Merged, non-edited 1926 and 1998 hydrographic data.
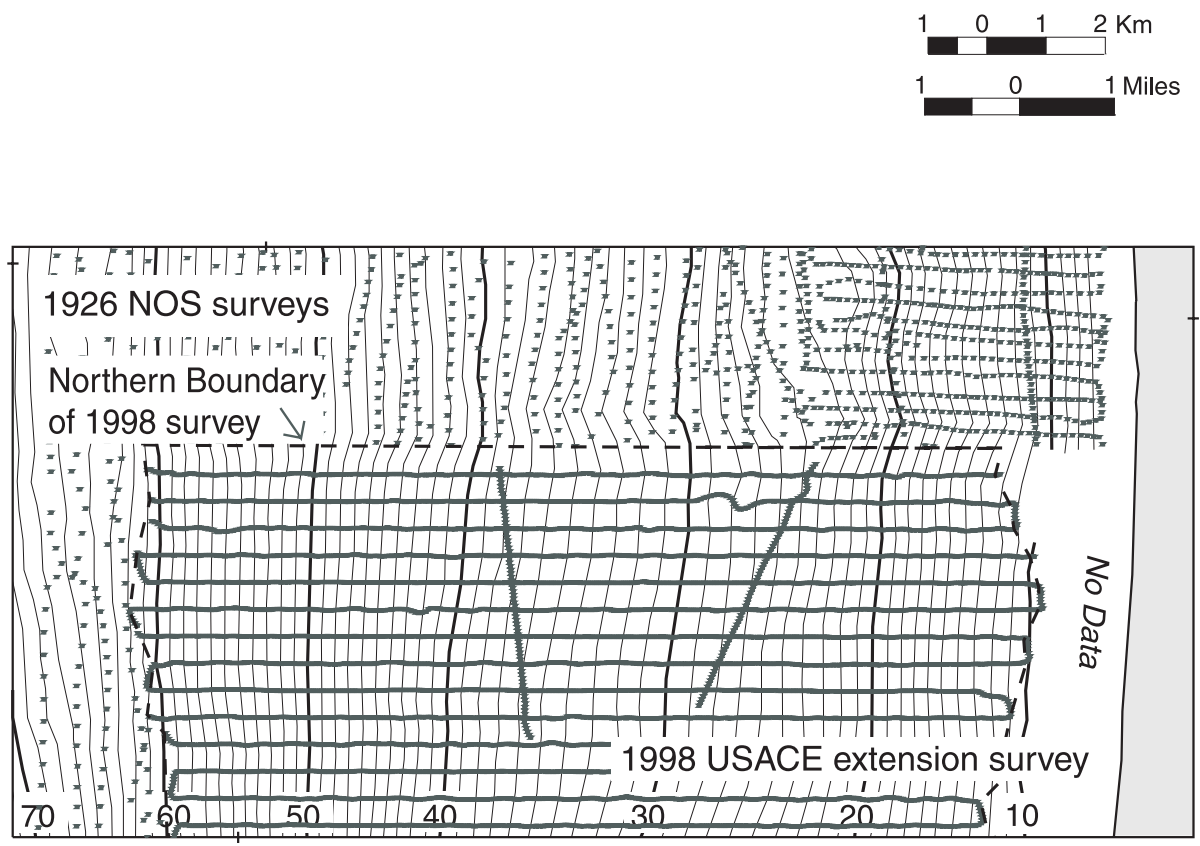

B. 1926 and 1998 hydrographic data and merged contours

Figure 6. Northern Columbia River inset maps. Note the minimal offset in the bathymetric contours across the 1926 and 1998 survey boundary. 


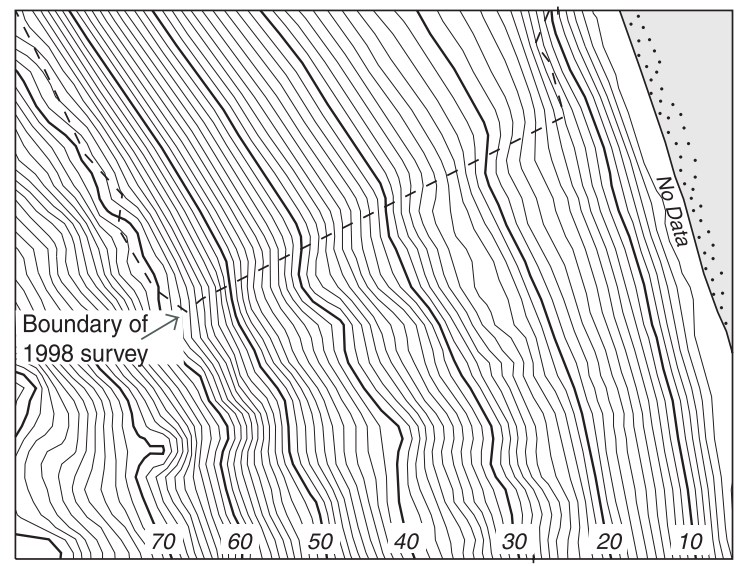

A. Merged, non-edited 1926 and 1998 hydrographic data.

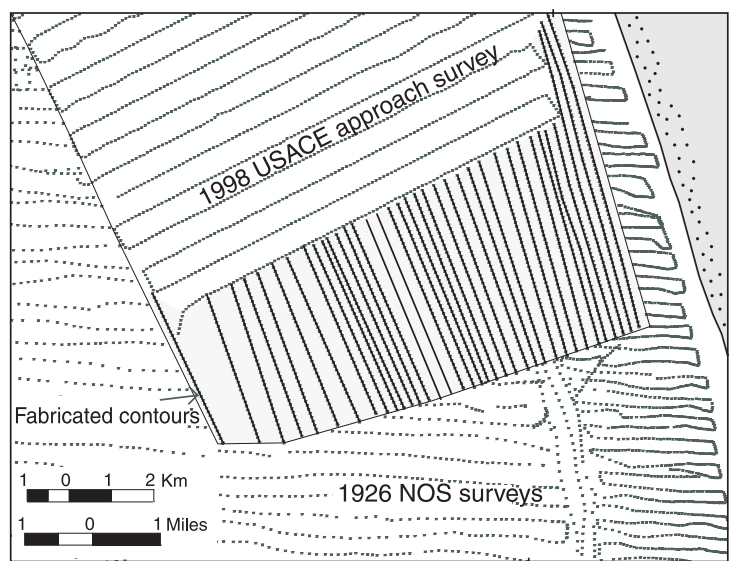

B. 1926, 1998, and fabricated hydrographic data. Shaded region is the area of deleted 1926 data.

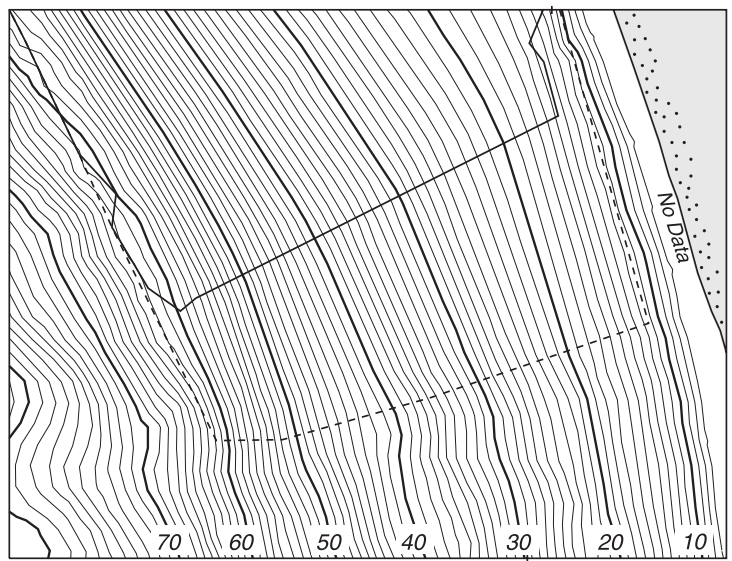

C. Edited and merged 1926 and 1998 hydrographic data.

Figure 7. Southern Columbia River inset maps. A) Note the large seaward offset in the bathymetric contours across the boundary between the 1926 and 1998 data sets. B) 1926 data were replaced with thirty-four NW-SE trending contours to; C) produce a smooth transition between the two data sets. 


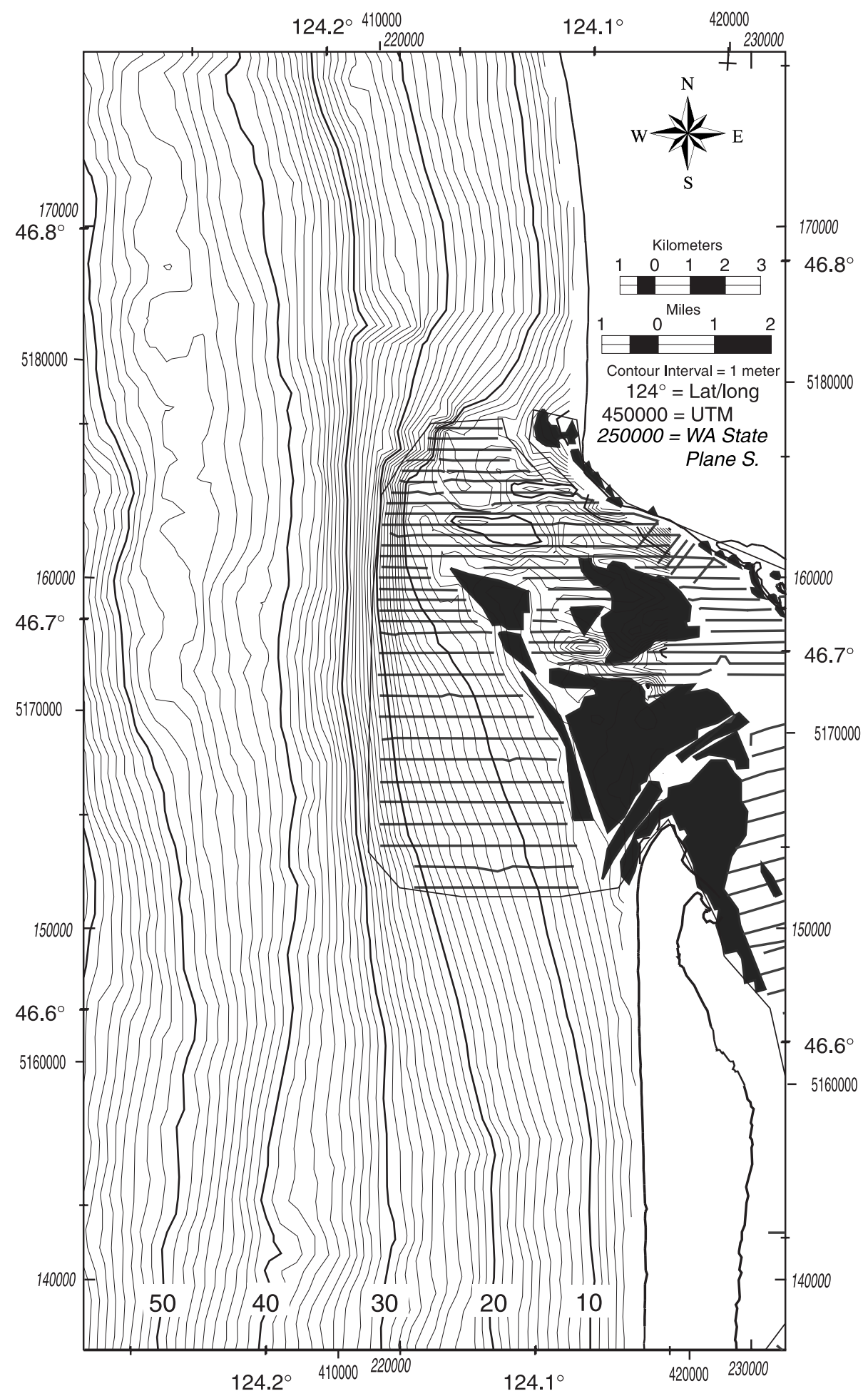

Figure 8. Bathymetric contours from merged and edited 1926/1998 data, and location of 1998 survey tracklines, Willapa Bay. The dark areas show regions of high-density SHOALS data coverage over tidal flats. 

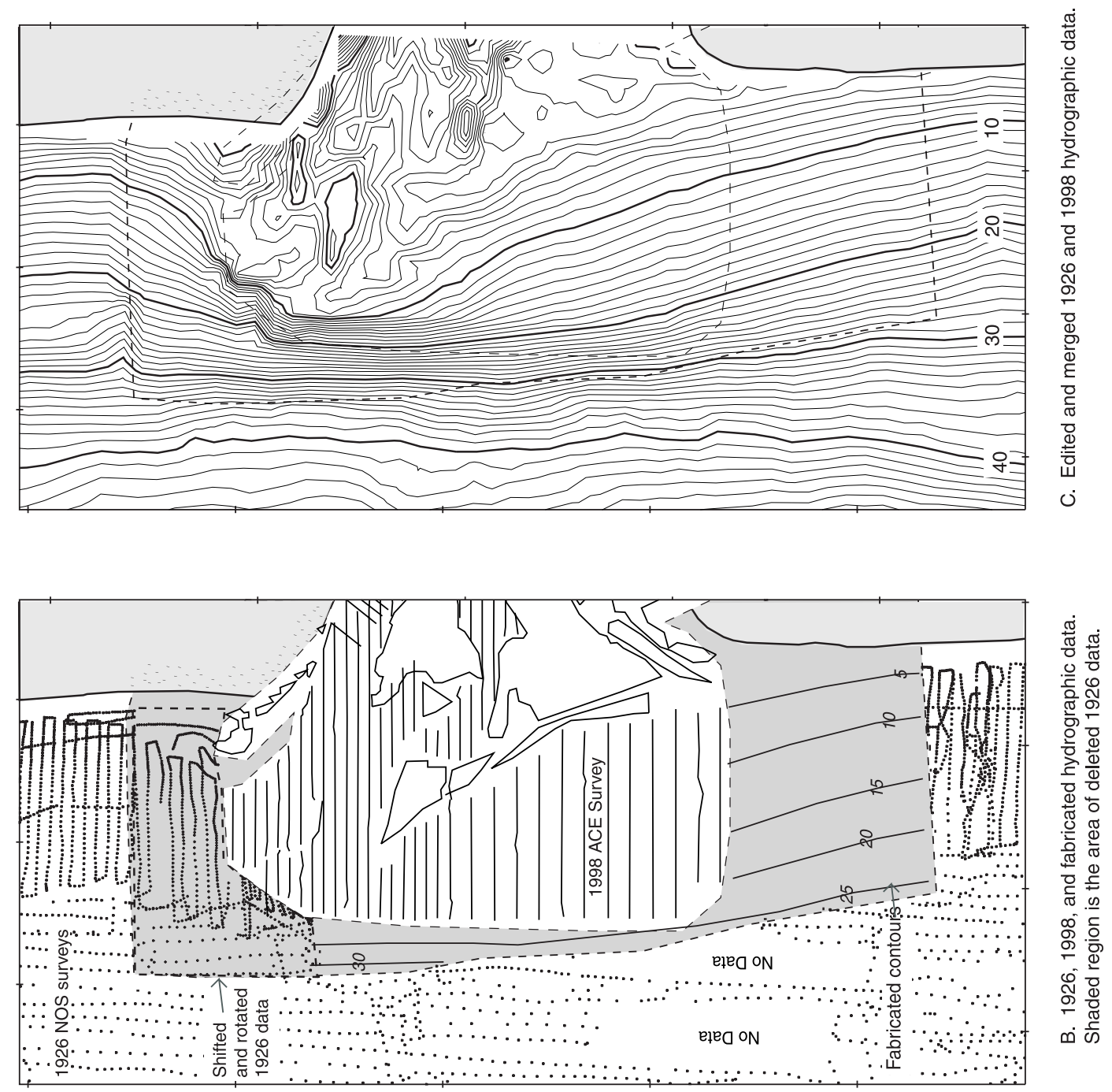


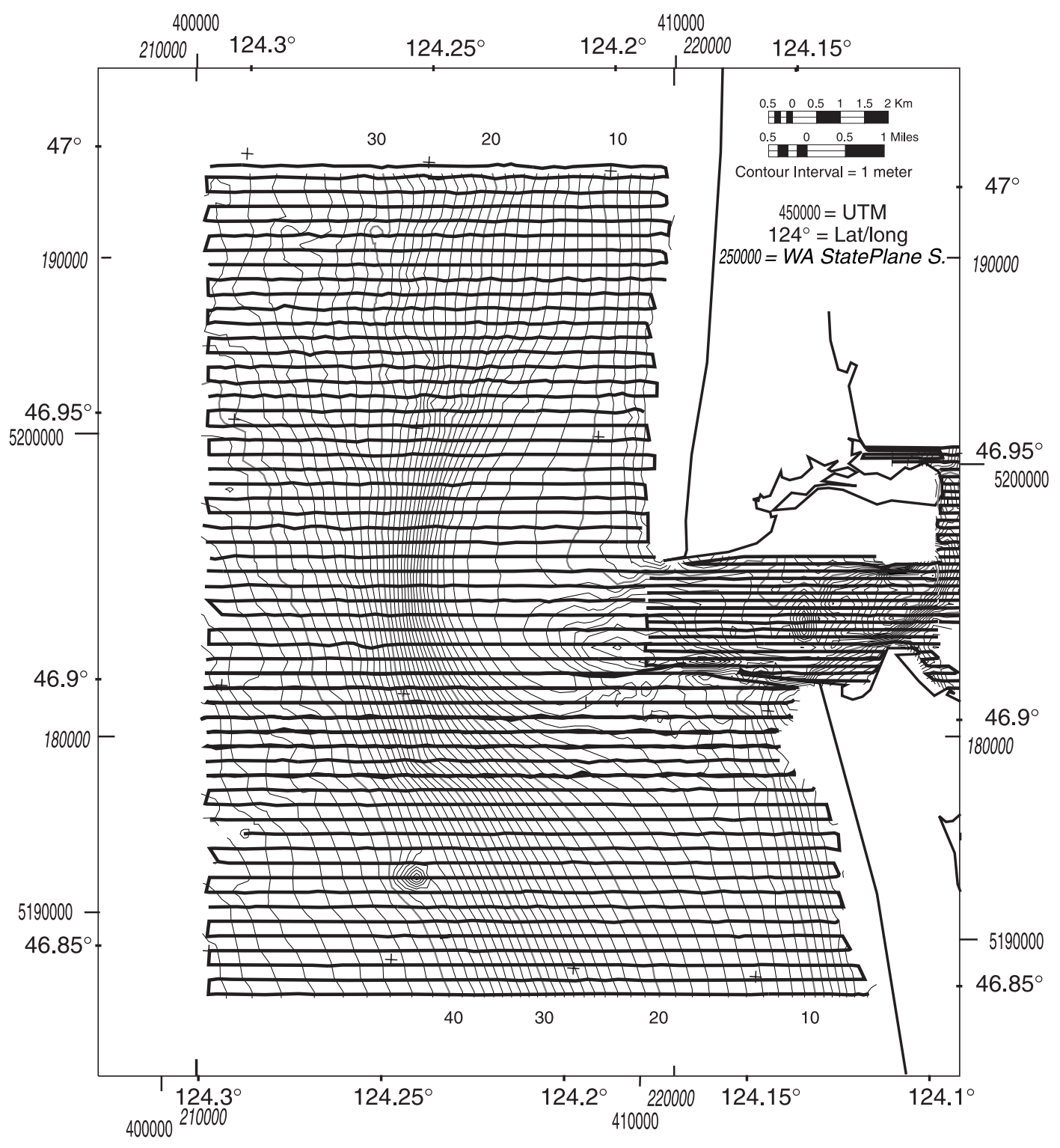

Figure 10. 1998 USACE annual survey tracklines for Grays Harbor. Data courtesy of the Seattle District Army Corps of Engineers. 


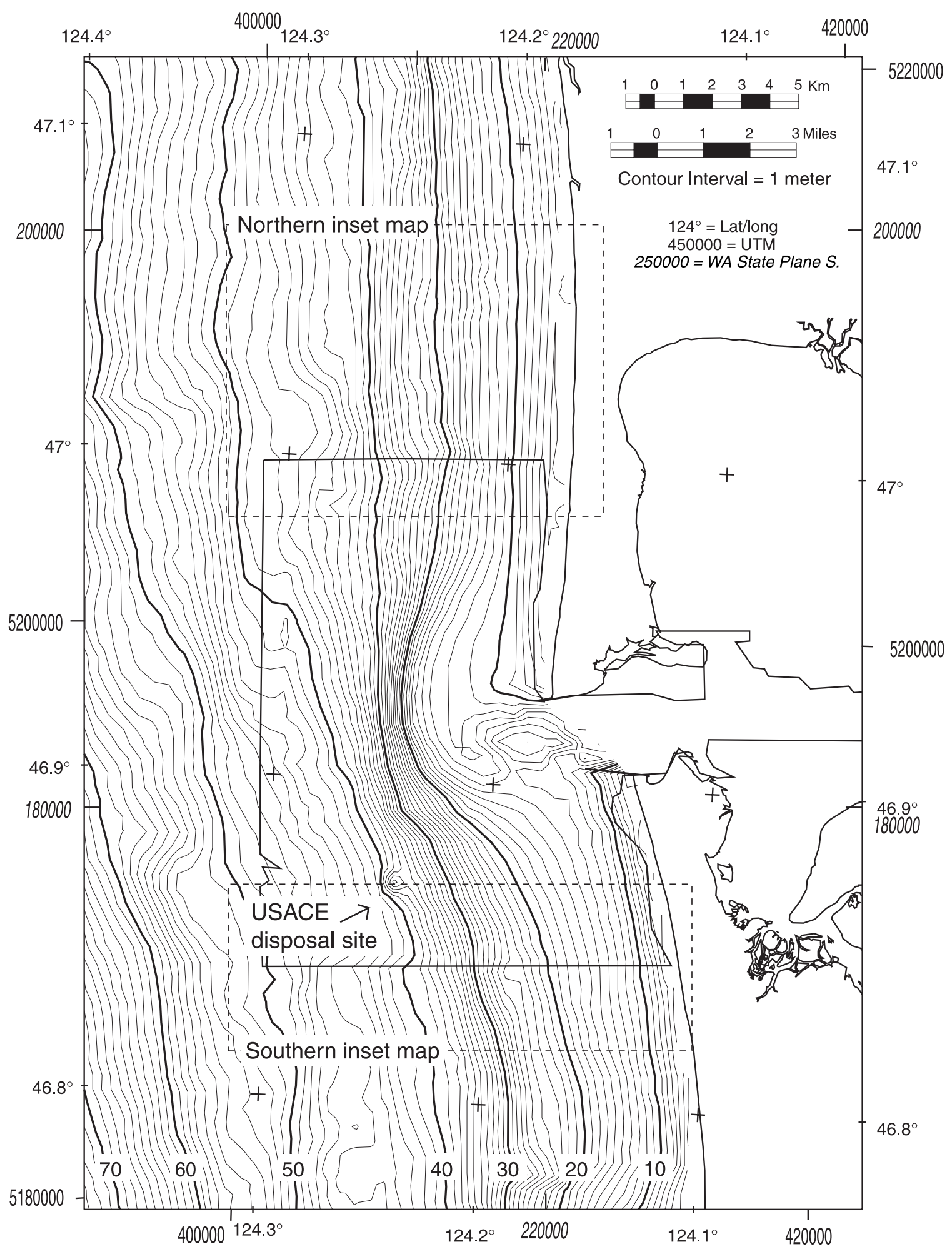

Figure 11. Bathymetric contours generated from merged and edited 1926/1998 data, Grays Harbor Washington. 


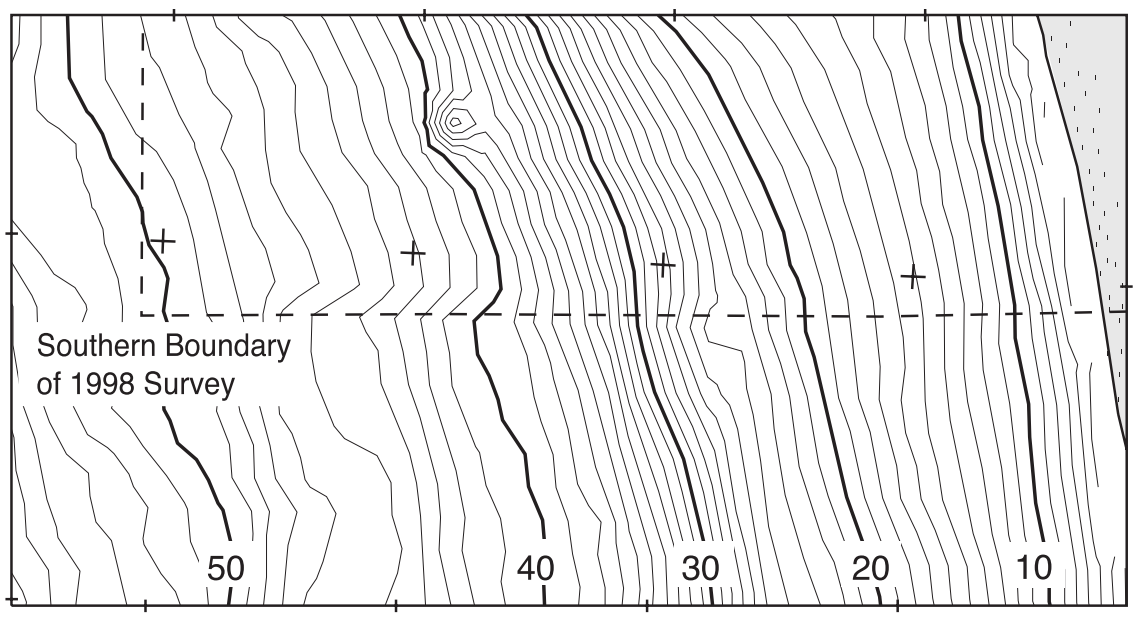

A. Merged, non-edited 1926 and 1998 hydrographic data.
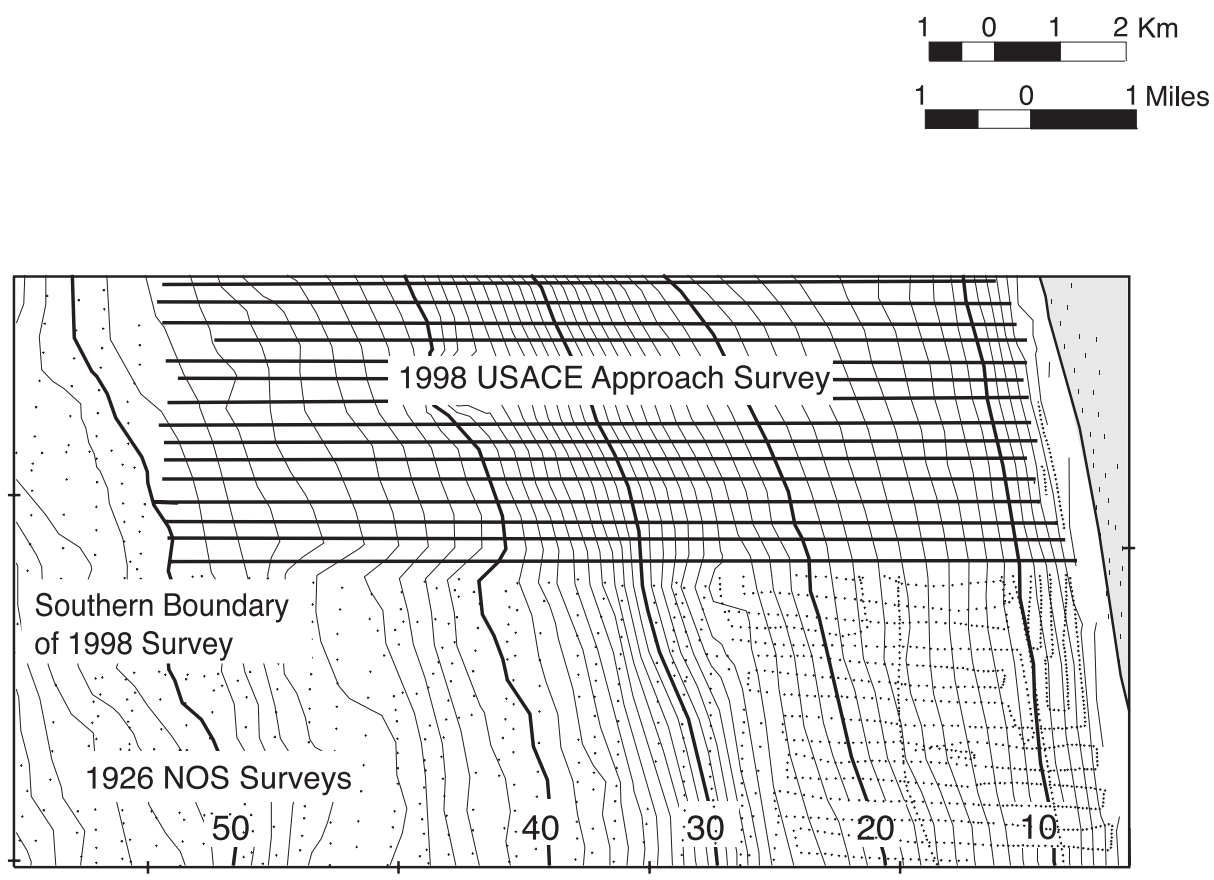

B. 1926 and1 998 hydrographic data and merged contours.

Figure 12. Southern Grays Harbor inset maps. Note the minimal offset in the bathymetric contours across the 1926/1998 survey boundary. 


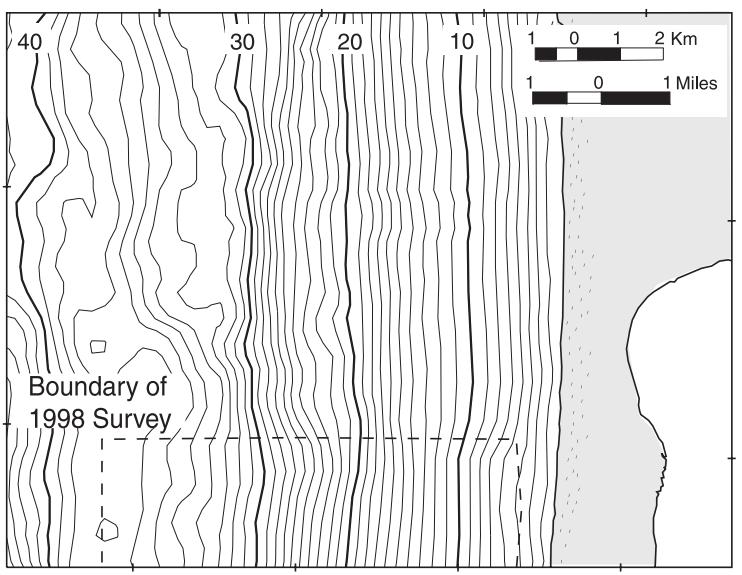

A. Merged, non-edited 1926 and 1998 hydrographic data.

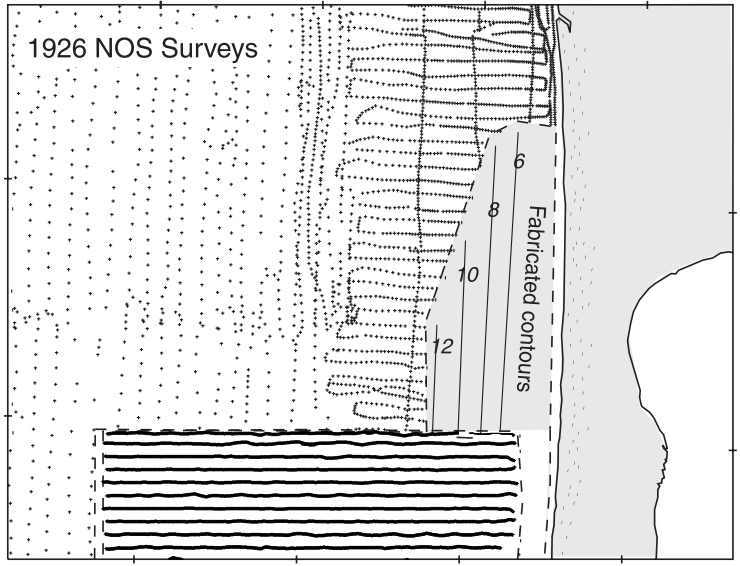

B. 1926,1998 , and fabricated hydrographic data. Shaded region is the area of deleted 1926 data.

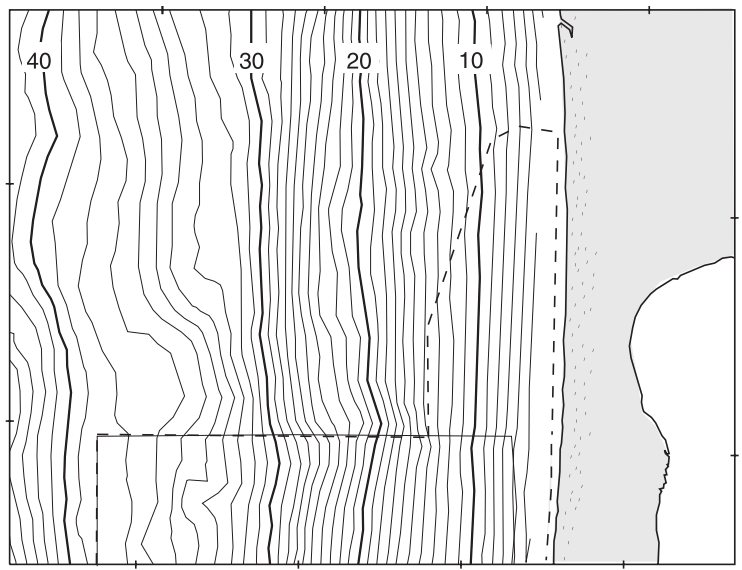

C. Edited and merged 1926 and 1998 hydrographic data.

Figure 13. Northern Grays Harbor inset maps. A) Note the large seaward offset of contours across the merged 1926/1998 data sets. B) To obtain smooth contours across this boundary, it was necessary to insert four NW-SE trending data contours. 


\section{ACKNOWLEDGEMENTS}

The authors would like to thank Eric Nelson of the Seattle District USACE for the Grays Harbor and Willapa Bay survey data, and H. Rod Moritz of the Portland District USACE for the Columbia River entrance survey data. Critical reviews of this report by Florence Wong and Guy Gelfenbaum of the U.S. Geological Survey, and George Kaminsky of the WA State Dept. of Ecology were most helpful and greatly appreciated. This report was completed as part of the Southwest Washington Coastal Erosion Study. This study is jointly funded by the Washington State Department of Ecology and the US Geological Survey, Coastal and Marine Geology Program.

\section{REFERENCES}

Flood, R., Ferrini, V., Gioson, L., and Zaleski, L., 2000. Preliminary results of a multibeam bathymetry and backscatter survey. In: Gelfenbaum and Kaminsky (eds.) Southwest Washington Coastal Erosion Study 1999 Workshop Report. U.S. Geological Survey Open-File Report OF 00-439. p. 81-83.

Gelfenbaum, G. and Kaminsky, G. (editors). 1999. Southwest Washington Coastal Erosion Workshop Report, 1998. U.S. Geological Survey Open-File Report OF 99-524.

Gelfenbaum, G. and Kaminsky, G. (editors). 2000. Southwest Washington Coastal Erosion Workshop Report, 1999. U.S. Geological Survey Open-File Report OF 00-439.

Gibbs, A. E. and Gelfenbaum, G., 1999. Bathymetric change off the Washington-Oregon coast,. Proceedings of Coastal Sediments '99, ASCE,. pp. 1627-1641.

Kaminsky, G.M., Ruggiero, P., Gelfenbaum, G., and Peterson, C. 1997. Long-term coastal evolution and regional dynamics of U.S. Pacific Northwest littoral cell. Proceedings of Coastal Dynamics '97, The International Conference on Coastal Research through Large Scale Experiments. pp. 614-623.

NOAA-NGDC, 1998. Marine Trackline and Geophysics CD-ROM, v 4.0. NOAA, Data announcement 98-MGG-04.

NOAA, 1994. NOAA Medium-Resolution Vector Shoreline CD-ROM (v. 1Beta, Sept. 1994). 


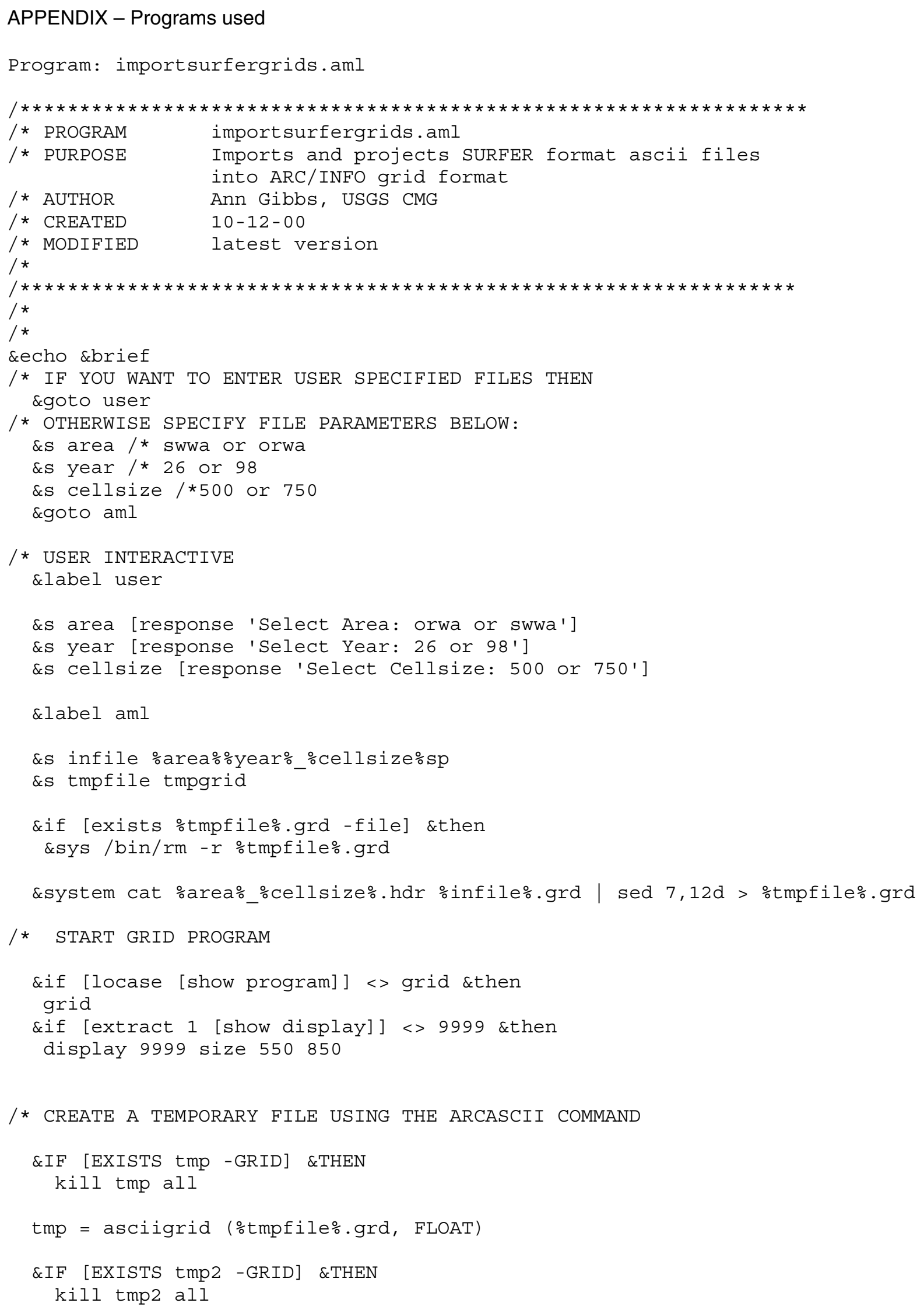




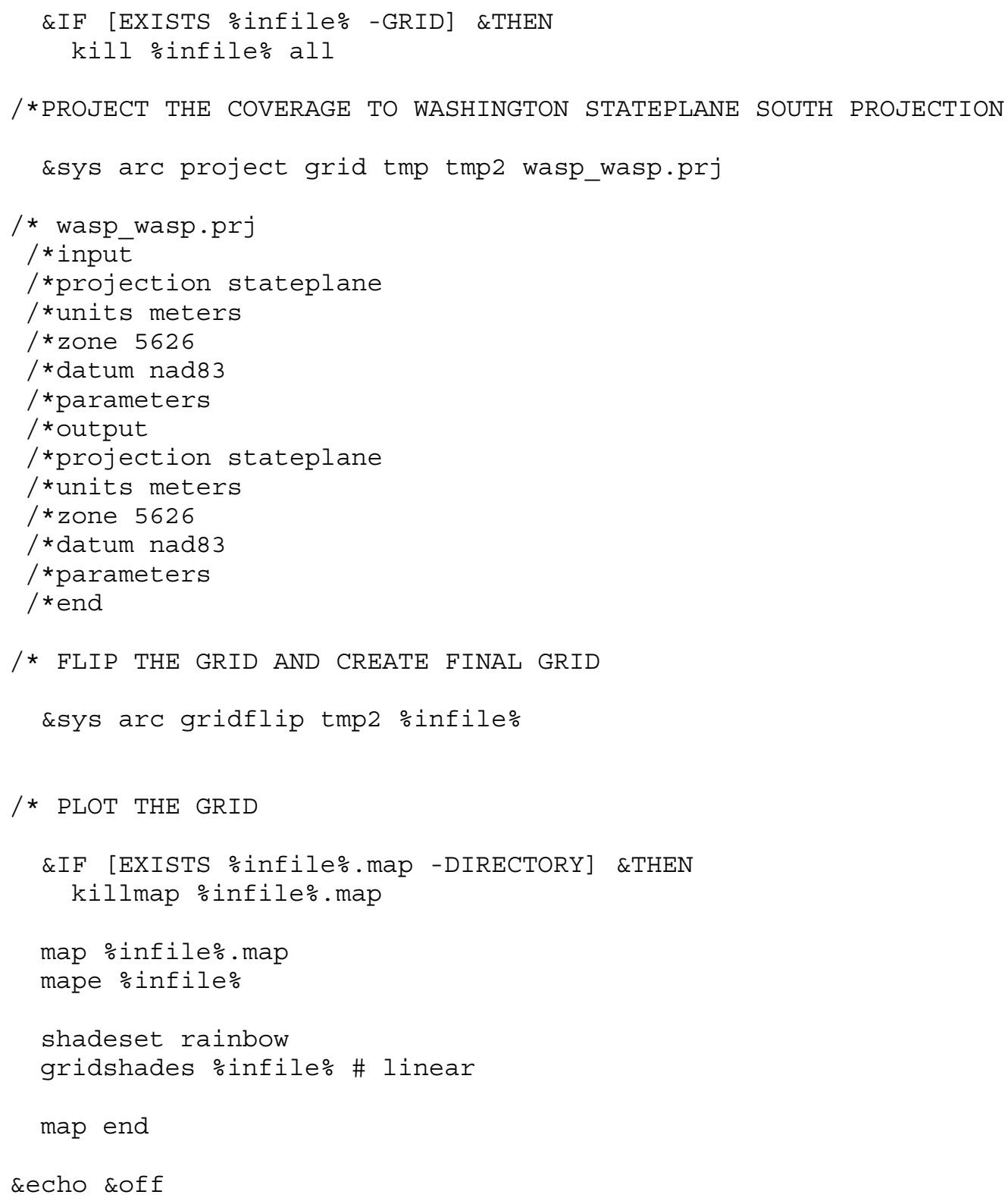




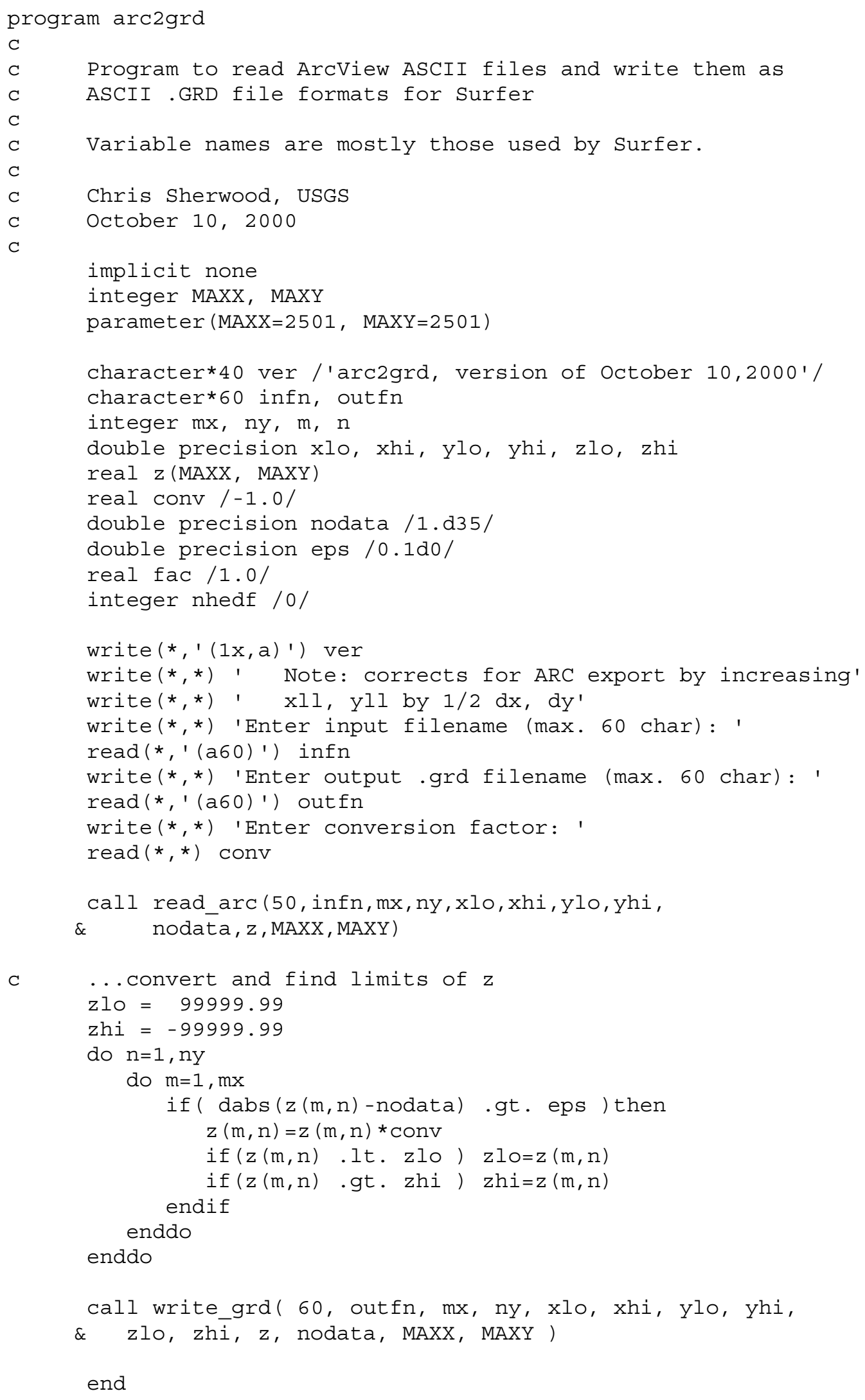




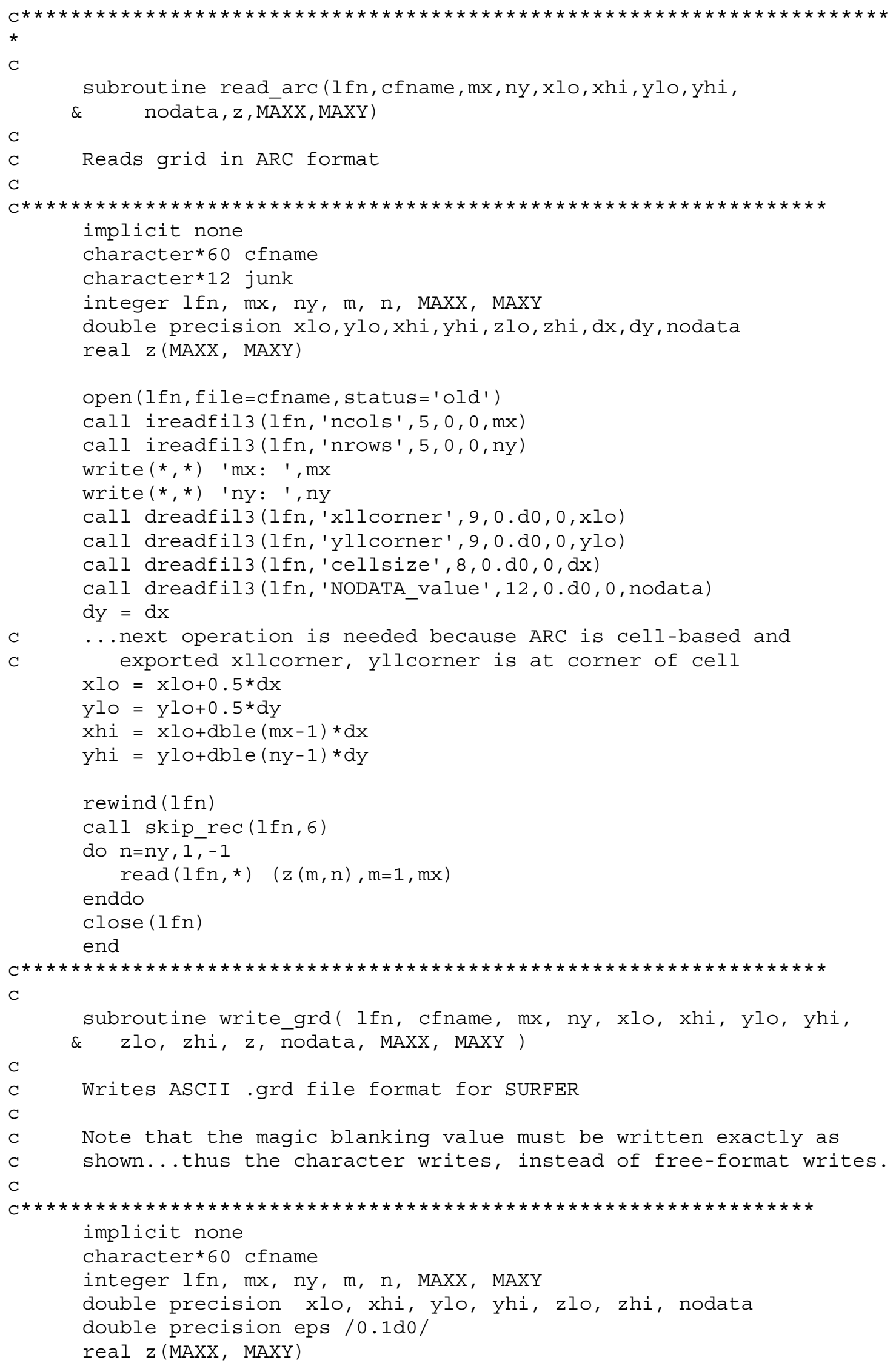




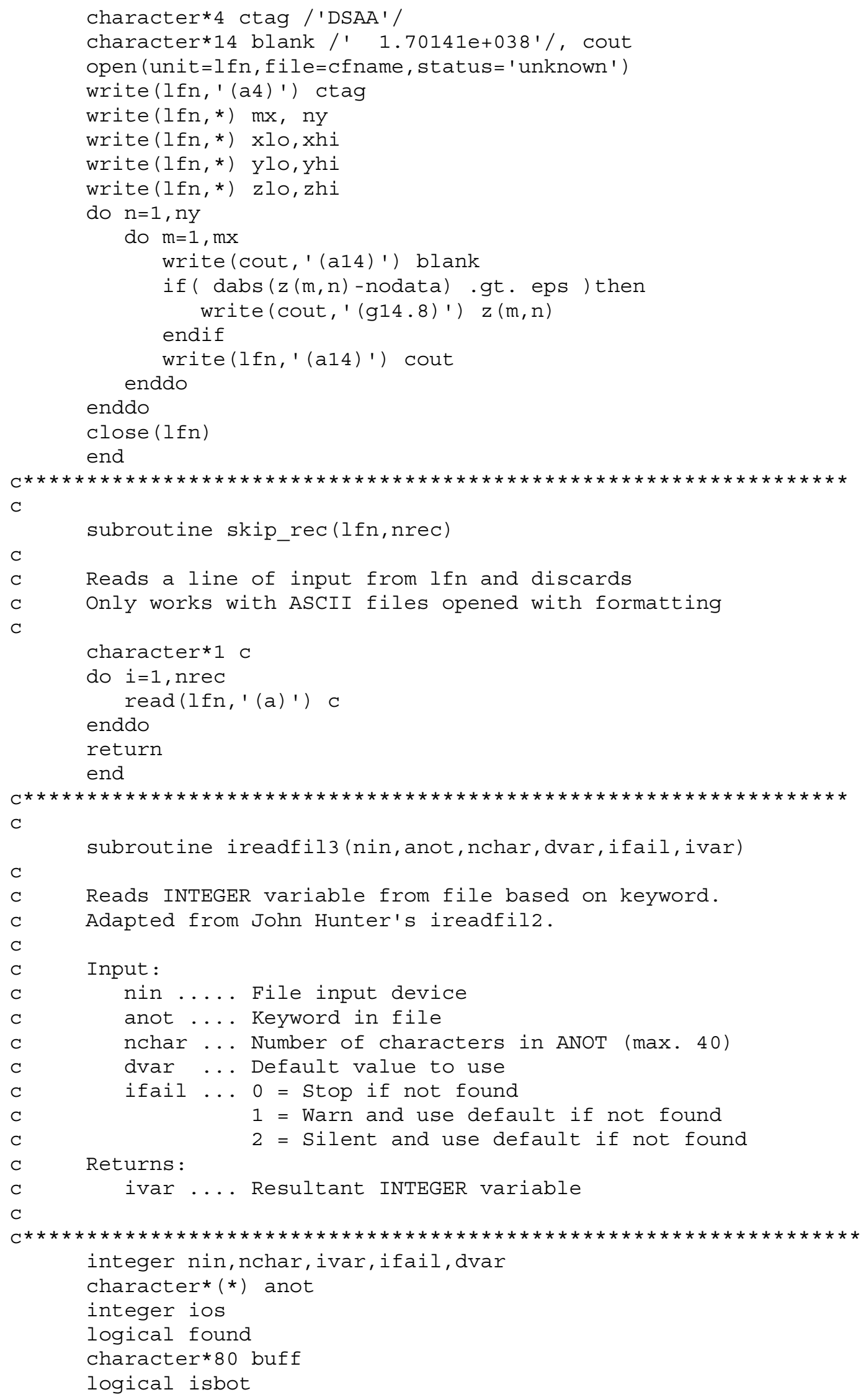




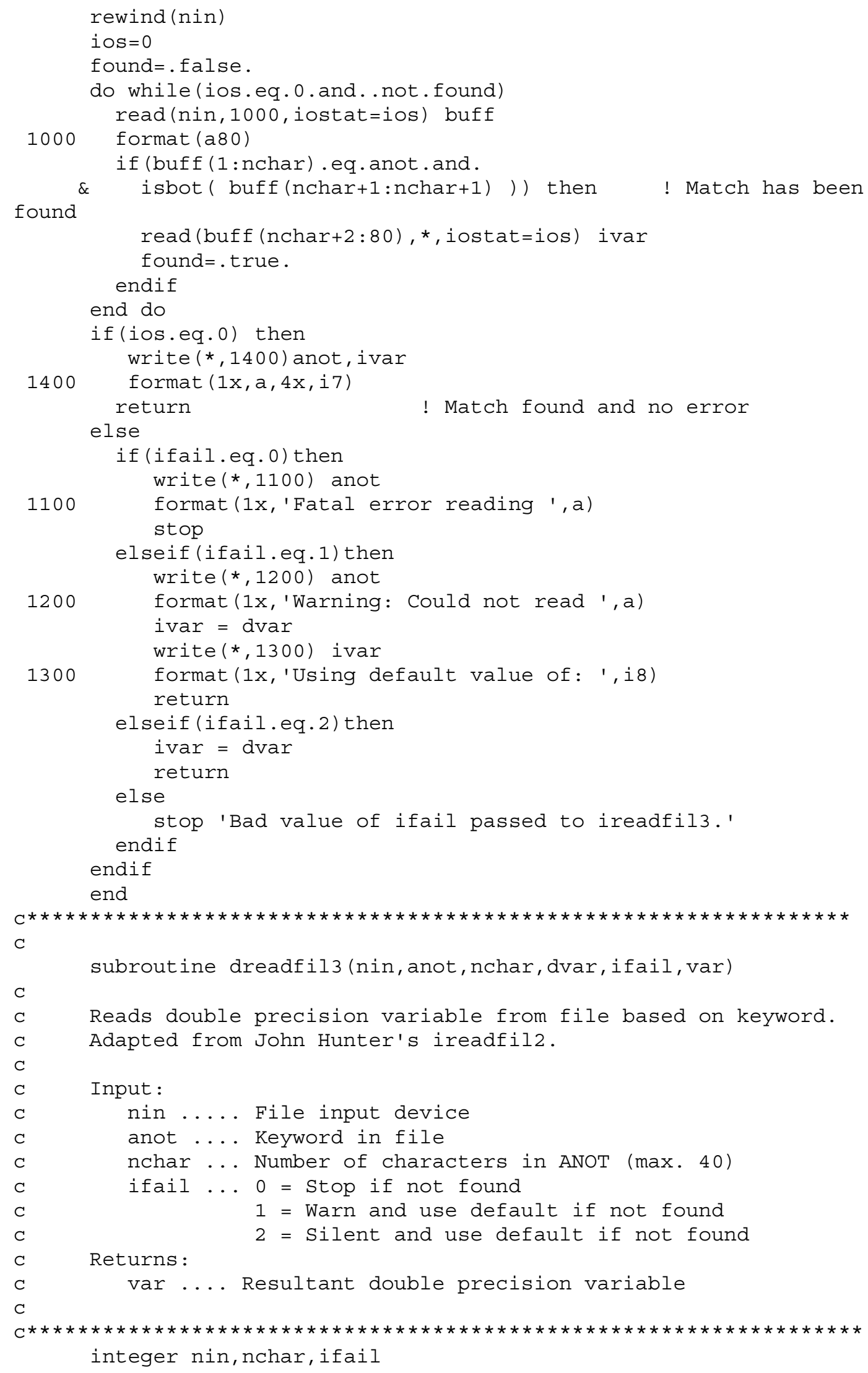




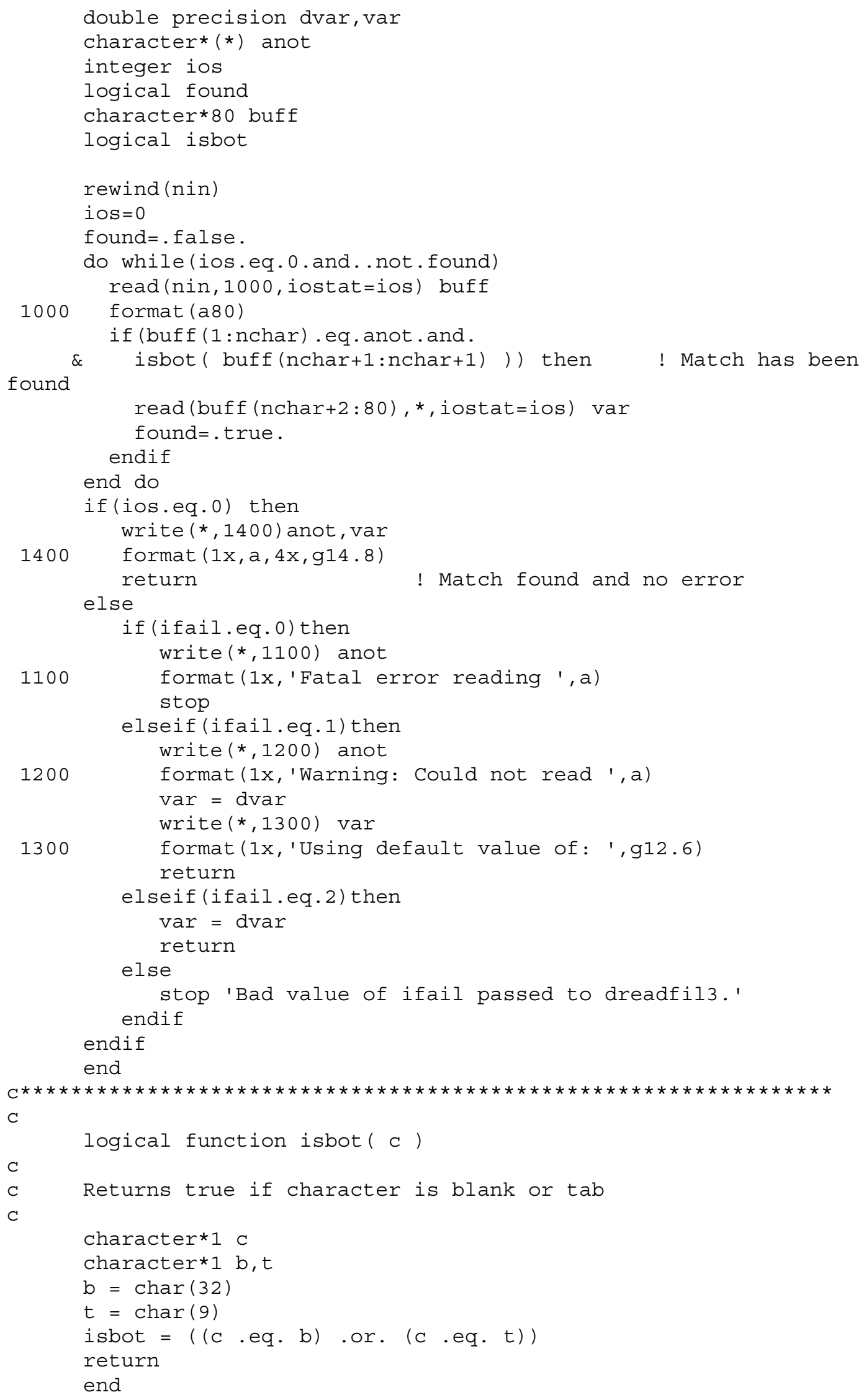

